\title{
Inadequate use of antibiotics in the covid-19 era: effectiveness of antibiotic therapy
}

\author{
Alejandro David Bendala Estrada ${ }^{*} \mathbb{0}$, Jorge Calderón Parra² , Eduardo Fernández Carracedo', \\ Antonio Muiño Míguez ${ }^{1}$, Antonio Ramos Martínez ${ }^{2}$, Elena Muñez Rubio ${ }^{2}$, Manuel Rubio-Rivas ${ }^{3}$, \\ Paloma Agudo ${ }^{4}$, Francisco Arnalich Fernández ${ }^{5}$, Vicente Estrada Perez ${ }^{6}$, María Luisa Taboada Martínez ${ }^{7}$ \\ Anxela Crestelo Vieitez ${ }^{8}$, Paula Maria Pesqueira Fontan ${ }^{9}$, Marta Bustamante ${ }^{10}$, Santiago J. Freire ${ }^{11}$, \\ Isabel Oriol-Bermúdez ${ }^{12}$, Arturo Artero ${ }^{13}$, Julián Olalla Sierra ${ }^{14}$, María Areses Manrique ${ }^{15}$, \\ H. Francisco Javier Carrasco-Sánchez ${ }^{16}$, Vanessa Carolina Vento ${ }^{17}$, Gema María García García ${ }^{18}$, \\ Pablo Cubero-Morais ${ }^{19}$, José-Manuel Casas-Rojo ${ }^{20}$ and Jesús Millán Núñez-Cortés ${ }^{1}$
}

\begin{abstract}
Background: Since December 2019, the COVID-19 pandemic has changed the concept of medicine. This work aims to analyze the use of antibiotics in patients admitted to the hospital due to SARS-CoV-2 infection.

Methods: This work analyzes the use and effectiveness of antibiotics in hospitalized patients with COVID-19 based on data from the SEMI-COVID-19 registry, an initiative to generate knowledge about this disease using data from electronic medical records. Our primary endpoint was all-cause in-hospital mortality according to antibiotic use. The secondary endpoint was the effect of macrolides on mortality.

Results: Of 13,932 patients, antibiotics were used in 12,238. The overall death rate was $20.7 \%$ and higher among those taking antibiotics (87.8\%). Higher mortality was observed with use of all antibiotics (OR 1.40,95\% Cl 1.21-1.62; $p<.001)$ except macrolides, which had a higher survival rate (OR 0.70, 95\% Cl 0.64-0.76; $p<.001)$. The decision to start antibiotics was influenced by presence of increased inflammatory markers and any kind of infiltrate on an $x$-ray. Patients receiving antibiotics required respiratory support and were transferred to intensive care units more often.

Conclusions: Bacterial co-infection was uncommon among COVID-19 patients, yet use of antibiotics was high. There is insufficient evidence to support widespread use of empiric antibiotics in these patients. Most may not require empiric treatment and if they do, there is promising evidence regarding azithromycin as a potential COVID-19 treatment.
\end{abstract}

Keywords: COVID-19, SARS-CoV-2, Antibiotics, Survival, Macrolides, Azithromycin

\section{Introduction-Background}

In late December 2019, a series of pneumonia cases of an unknown etiology were diagnosed in Wuhan, Hubei province (China). One week later, a new

${ }^{*}$ Correspondence: alejandro.bendala@gmail.com

${ }^{1}$ Internal Medicine Department, Gregorio Marañón General University Hospital, Madrid, Spain

Full list of author information is available at the end of the article betacoronavirus was identified and named severe acute respiratory syndrome coronavirus 2 (SARS-CoV-2), the virus that causes coronavirus disease 2019 (COVID-19) $[1,2]$. In March 2020, this new disease was declared a pandemic by the World Health Organization (WHO) and as of May 31st, 2021, more than 169 million cases of COVID-19 and more than 3,500,000 deaths from it had been reported globally. Spain in particular has been one of the countries most affected by the COVID-19 
pandemic, with more than 3,500,000 cases and 79,000 deaths as of that date [3-5]. Other most hitted countries by COVID-19 are India, United States and Brazil $[6,7]$.

Currently, in spring 2021, the available knowledge on how to manage patients with COVID-19 is incomplete and highly fragmented [8]. The U.S. Food and Drug Administration (FDA) has approved few drugs for treating the disease as Remdesivir. Nevertheless, physicians are using drugs approved for other indications while others are being studied. In this context, this work reflects on how to approach the challenge of treating this illness, particularly in regard to the use of antibiotics $[9,10]$.

The etiology of community-acquired pneumonia among hospitalized adults is unknown in $62 \%$ of cases, viral in $27 \%$ of cases, and bacterial in $14 \%$ of cases. Prior to December 2019, coronaviruses were responsible for $10 \%$ of viral pneumonias (2.7\% of all etiologies) [11]. In lower respiratory tract infections, viruses can induce structural changes as reduction of ciliary function and decrease epithelial barrier function that can favor bacterial infections. It is not clear if antibiotics are necessary for these viral pneumonias [12-14]. Treatment guidelines for community-acquired pneumonia recommend initial empiric antibiotic therapy for possible bacterial infection or co-infection, given that they often coexist and there are no clear diagnostic tests for determining if the pneumonia is solely due to a virus at the time of onset $[15,16]$. On the other hand, treatment decisions must be weighed taking into consideration the rise of multidrug-resistant bacteria and the fact that patients can develop complications associated with antibiotic use $[17,18]$.

Currently, there are no clear estimates on the incidence of bacterial co-infection in patients with COVID19 and no clinical trials have been conducted on the use of empiric antibiotics in these patients [9]. Fluoroquinolones, such as ciprofloxacin and moxifloxacin, have been analyzed for their potential capacity to bind to the SARS-CoV-2 protease Mpro, blocking replication [19]. Furthermore, beta-lactam antibiotics are being evaluated in critically ill patients with SARS-CoV-2 infection, but more clinical trials are necessary in order to properly evaluate results [20].

Some researchers have concentrated on the use of macrolides in patients with COVID-19. Some macrolides, such as azithromycin and clarithromycin, are being studied not only for their anti-bacterial activity, but also their immunomodulatory and anti-inflammatory effects. They could be particularly useful in viral infections such as COVID-19, which are associated with an excessive inflammatory response, through the antibiotics' attenuation of cytokine production [21-23]. Likewise, azithromycin has shown effects against virus replication and internalization processes in other viruses such as influenza A virus subtype H1N1 or Zika virus [24, 25].

With this background, this work aims to analyze the use of antibiotics in patients admitted to the hospital due to SARS-CoV-2 infection.

\section{Methods}

This work is a multicenter, nationwide, observational study based on patient data obtained from the SEMICOVID-19 Registry.

\section{Study design and population}

The SEMI-COVID-19 Registry is an enterprise of the Spanish Society of Internal Medicine (SEMI, for its initials in Spanish) to advance knowledge on the epidemiology, clinical progress, risk factors, complications of patients infected with SARS-CoV-2 with the aim of improving SARS-CoV-2 treatment. The list of SEMICOVID-19 Registry members can be found in Additional file 1.

Informed consent was obtained from all participants for using of their medical data for all research derived from the SEMI-COVID-19 registry. The registry is an anonymized online database of retrospective data on consecutive adult patients with COVID-19 hospitalized in internal medicine departments throughout Spain from March 1 to May 23, 2020. The diagnosis was confirmed microbiologically by real time transcription polymerase chain reaction (Rt-PCR) testing of a nasopharyngeal sample. Exclusion criteria were subsequent admissions of the same patient and denial or withdrawal of informed consent. Patients were cared for at their attending physician's discretion, according to local protocols and their clinical judgment. Patient inclusion flow chart is shown in Fig. 1.

The registry includes data on more than 300 variables in categories such as:

- Sociodemographic and epidemiological data

- Personal medical and medication history

- Symptoms and physical examination findings upon admission

- Laboratory test results

- Radiological findings and their progress

- Pharmacological treatment and ventilatory support

- In-hospital complications and causes of death

More in-depth information on the registry and preliminary results are available in a previously published work [4].

The SEMI-COVID-19 Registry was approved by the Provincial Research Ethics Committee of Málaga (Spain). 


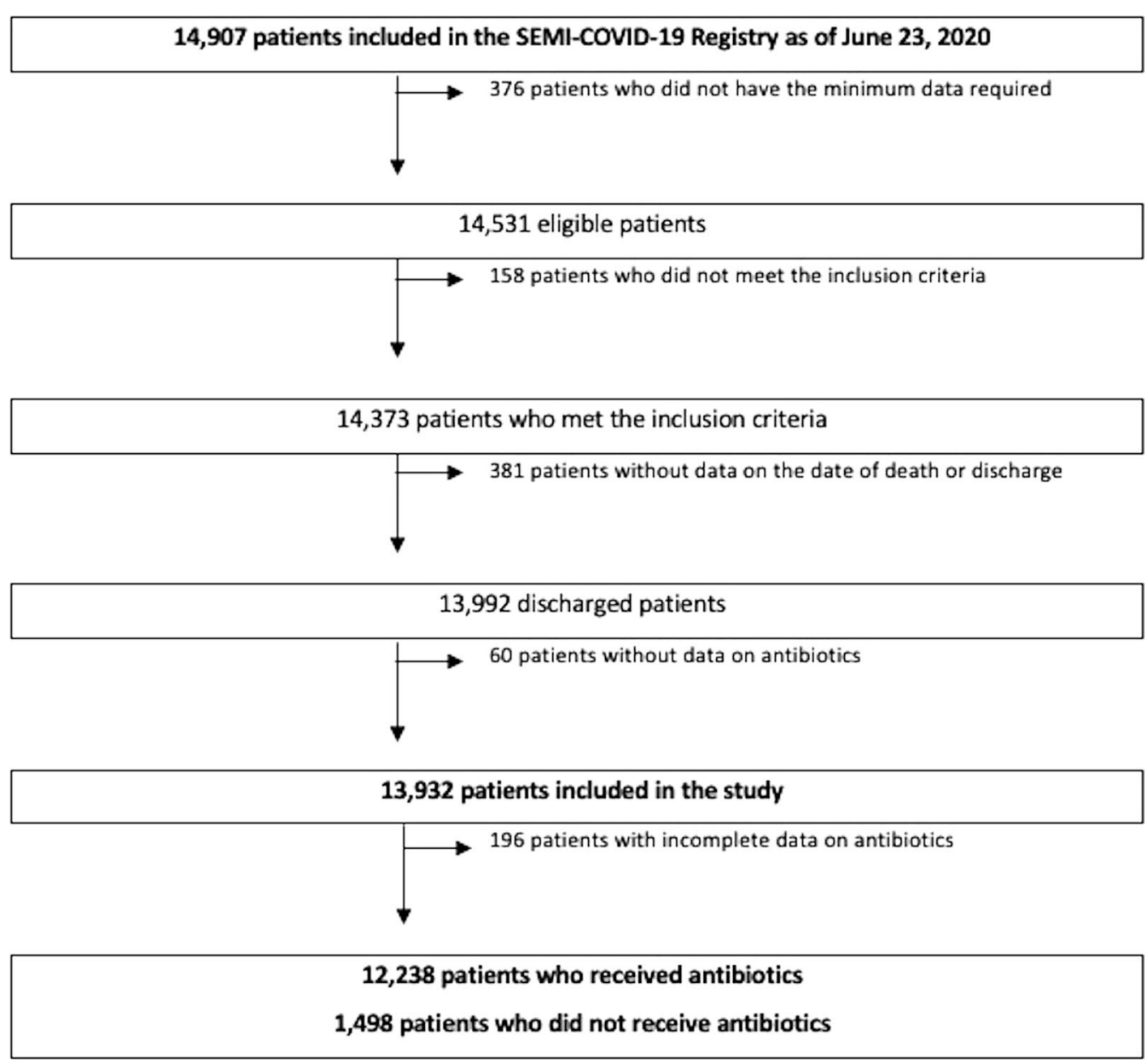

Fig. 1 Patient inclusion flow chart

\section{Study conclusion}

The primary endpoint was all-cause in-hospital mortality according to use of antibiotic therapy. The secondary endpoint was the specific effect of macrolides on the all-cause mortality rate. The follow-up period was from admission to discharge or death, including early readmissions.

We have analyzed the criteria for the use of antibiotics, any relationship to epidemiological or microbiological factors, and the evolution of analytical and radiological parameters.

\section{Literature search}

A literature search was conducting using the MEDLINE database with the following search terms: "antibiotics and COVID-19," "bacterial co-infections and SARS-CoV-2," and "azithromycin and COVID-19." The most up-to-date evidence and all information regarding antibiotics, macrolides, and bacterial co-infections in COVID-19 reported in English or Spanish were selected.

\section{Data analysis}

The patients were initially divided into two groups according to use of antibiotic therapy. The first group, which included 12,238 patients, received antibiotics and the second, with 1498 patients, did not receive antibiotics.

Continuous quantitative variables were tested for normal distribution using rates of skewness and kurtosis, Levene's test, or the Kolmogorov-Smirnov test, as appropriate. These variables are expressed as medians and interquartile range (IQR). Comparisons between groups were made using the Student's T-test, Mann-Whitney U test, Wilcoxon test, analysis of variance (ANOVA), or the Kruskal-Wallis test. Categorical variables are expressed absolute values and percentages. Differences in proportions were analyzed using the Chi-square test, McNemar's test, or Fisher's exact test, as appropriate. 
We also used a bivariate logistic regression to evaluate the relationship between groups of antibiotics and mortality. A multivariate analysis was carried out to correct for confounding variables using clinically relevant, statistically significant variables $(p<0.001)$ identified in the univariate analysis.

Measures of association are expressed as odds ratio (OR) with 95\% confidence intervals (95\% CI). Statistical analysis was carried out using STATA software (v14.2). Statistical significance was established as $p<0.05$.

\section{Results}

\section{Demographics, mortality, and clinical features}

Patients were initially divided into two groups according to whether they received antibiotic therapy or not. Of a total of 13,932 patients included in this study, antibiotics were used in 12,238 (87.8\%) and not used in 1498 (10.8\%). A higher mortality rate was observed with the use of all antibiotics except macrolides, which showed a higher survival rate (OR 0.70, 95\% CI 0.64-0.76; $p<0.001$ ). Tables 1 and 2 show the type of antibiotic used and the number of patients who died or survived. Microbiological findings are shown on Table 3.

Differences in fatality have been noted according to where the virus was acquired: mortality was higher among those who acquired the infection nosocomially (OR 1.98, 95\% CI 1.71-2.30; $p<0.001$ ) or in a nursing home (OR 2.80, 95\% CI 2.46-3.18; $p<0.001$ ) compared to those who were infected in the community (Table 4). Differences regarding the use of antibiotics and macrolides

Table 1 Use of antibiotic therapy in COVID-19 patients admitted to internal medicine departments

\begin{tabular}{lr}
\hline Antibiotic used & \multicolumn{1}{l}{$\begin{array}{l}\text { No. (Total } \\
\mathbf{n = 1 3 , 9 3 2 )} \\
\mathbf{( \% )}\end{array}$} \\
\hline Any antibiotic & $12,238(87.8)$ \\
Beta-lactams & $10,031(72.0)$ \\
Macrolides & $8382(60.2)$ \\
Quinolones & $1850(13.3)$ \\
\hline
\end{tabular}

It was possible for a patient to receive more than one antibiotic concomitantly
Table 3 Microbiological findings-SARS-CoV-2 infection

\begin{tabular}{|c|c|c|}
\hline & $\begin{array}{l}\text { No. (Total } \\
n=13,932)\end{array}$ & No. (\%) \\
\hline Confirmed COVID-19 & 13,932 & $13,932(100.0)$ \\
\hline \multicolumn{3}{|l|}{ Acquisition of COVID-19 } \\
\hline Community & 13,870 & $11,806(85.1)$ \\
\hline Nosocomial & & $908(6.6)$ \\
\hline Nursing home & & $1156(8.3)$ \\
\hline \multicolumn{3}{|c|}{ Source of positive sample for SARS-CoV-2 } \\
\hline Nasopharyngeal swab & 13,672 & $13,396(98.0)$ \\
\hline Sputum & & $224(1.6)$ \\
\hline Bronchoalveolar lavage (BAL) & & $52(0.4)$ \\
\hline \multicolumn{3}{|l|}{ Results of the first PCR } \\
\hline Negative & 13,723 & $1660(12.1)$ \\
\hline Positive & & $12,063(87.9)$ \\
\hline \multicolumn{3}{|l|}{ Results of urine antigens } \\
\hline Negative & 13,570 & $6168(45.5)$ \\
\hline Any positive & & $198(1.5)$ \\
\hline Positive Pneumococcus & & $179(1.3)$ \\
\hline Positive Legionella & & $12(0.1)$ \\
\hline Both positive & & $7(0.1)$ \\
\hline Not performed & & $7204(53.1)$ \\
\hline \multicolumn{3}{|l|}{ HIV serology test } \\
\hline Not performed & 13,793 & $5860(42.5)$ \\
\hline Negative & & $7844(56.9)$ \\
\hline Positive & & $89(0.7)$ \\
\hline
\end{tabular}

in particular according to where the infection was contracted are shown in Tables 5 and 6. Multivariate analyses of mortality based on the use of antibiotics and specifically on the use of macrolides were carried out with the possible confounding variables of age, degree of dependence, and place of disease acquisition. The results are shown in Tables 7 and 8.

Older age was a factor that differed between those who received antibiotics versus those who did not in a significant manner (69 years [IQR 56-79] vs. 67 years [IQR $52-80] ; p<0.001)$. There was a lower rate of antibiotic use among patients with dementia $(9.9 \%$ vs. $11.7 \% ; p<0.05)$, neurodegenerative disease $(8.9 \%$ vs. $11.4 \% ; p<0.05)$, and

Table 2 Antibiotic used and relationship to mortality

\begin{tabular}{|c|c|c|c|c|c|}
\hline Antibiotic used & Overall $(n=13,932)(\%)$ & $\begin{array}{l}\text { Survivors } n=11,042 \\
(\%)\end{array}$ & $\begin{array}{l}\text { Deceased } n=2890 \\
(\%)\end{array}$ & Odds ratio $(95 \% \mathrm{Cl})$ & $p$ value \\
\hline Any antibiotic & $12,238(87.8)$ & $9641(88.5)$ & $2597(91.4)$ & $1.39(1.20-1.61)$ & $<0.001$ \\
\hline Beta-lactams & $10,031(72.0)$ & $7709(70.0)$ & $2322(80.5)$ & $1.77(1.60-1.96)$ & $<0.001$ \\
\hline Macrolides & $8382(60.2)$ & $6845(62.2)$ & $1537(53.5)$ & $0.70(0.64-0.76)$ & $<0.001$ \\
\hline Quinolones & $1850(13.3)$ & $1363(12.5)$ & $487(17.1)$ & $1.44(1.29-1.62)$ & $<0.001$ \\
\hline
\end{tabular}


Table 4 Mcrobiological findings and relationship to mortality

\begin{tabular}{|c|c|c|c|c|c|c|}
\hline & Total $(n=13,932)$ & No. (\%) & $\begin{array}{l}\text { Survivors } \\
n=11,042(\%)\end{array}$ & $\begin{array}{l}\text { Deceased } \\
n=2890(\%)\end{array}$ & Odds ratio $(95 \% \mathrm{Cl})$ & $p$ value \\
\hline \multicolumn{7}{|c|}{ Acquisition of COVID-19 } \\
\hline Community & 13,870 & $11,806(85.1)$ & $9653(87.8)$ & $2153(74.9)$ & 1. (ref) & - \\
\hline Nosocomial & & $908(6.6)$ & $630(5.7)$ & $278(9.7)$ & $1.98(1.71-2.30)$ & $<0.001$ \\
\hline Nursing Home & & $1156(8.3)$ & $712(6.5)$ & $444(15.4)$ & $2.80(2.46-3.18)$ & $<0.001$ \\
\hline \multicolumn{7}{|c|}{ Results of urine antigens } \\
\hline Negatives & 13,570 & $6168(45.5)$ & $5086(47.3)$ & $1082(38.5)$ & 1. (ref) & - \\
\hline Any positive & & $198(1.5)$ & $146(1.4)$ & $52(1.9)$ & $1.67(1.21-2.31)$ & 0.002 \\
\hline Not performed & & $7204(53.1)$ & $5529(51.4)$ & $1675(59.6)$ & $1.42(1.31-1.55)$ & $<0.001$ \\
\hline
\end{tabular}

Table 5 Microbiological findings according to use of antibiotics

\begin{tabular}{lcccc}
\hline & Total $(\mathbf{n = 1 3 , 9 3 2 )}$ & No. (\%) & $\begin{array}{l}\text { With antibiotics } \\
\mathbf{n = 1 2 , 2 3 8 ( \% )}\end{array}$ & $\begin{array}{l}\text { Without antibiotics } \\
\mathbf{n = 1 4 9 8}(\%)\end{array}$ \\
\hline $\begin{array}{l}\text { Acquisition of COVID-19 } \\
\text { Community }\end{array}$ & 13,674 & $11,633(85.1)$ & $10,465(85.9)$ & $1168(78.7)$ \\
$\quad$ Nosocomial & $891(6.5)$ & $760(6.2)$ & $131(8.8)$ \\
$\quad$ Nursing Home & $1150(8.4)$ & $965(7.9)$ & $185(12.5)$ \\
$\begin{array}{l}\text { Results of urine antigens } \\
\text { Negative }\end{array}$ & 13,381 & $6077(45.4)$ & $5569(46.6)$ & $508(35.6)$ \\
Any positive & & $196(1.5)$ & $189(1.6)$ & $7(0.5)$ \\
$\quad$ Not performed & & $7108(53.1)$ & $6195(51.8)$ & $913(63.9)$ \\
\hline
\end{tabular}

Table 6 Microbiological findings according to use of macrolides

\begin{tabular}{|c|c|c|c|c|c|}
\hline & Total $(n=13,932)$ & No. (\%) & $\begin{array}{l}\text { Macrolides } n=8382 \\
(\%)\end{array}$ & $\begin{array}{l}\text { Without macrolides } \\
\mathrm{n}=5502(\%)\end{array}$ & $p$ value \\
\hline \multicolumn{6}{|c|}{ Acquisition of COVID-19 } \\
\hline Community & 13,822 & $11,766(85.1)$ & $7315(87.5)$ & $4451(81.5)$ & $<0.001$ \\
\hline Nosocomial & & $903(6.5)$ & $460(5.5)$ & $443(8.1)$ & \\
\hline Nursing Home & & $1153(8.3)$ & $588(7.0)$ & $565(10.4)$ & \\
\hline \multicolumn{6}{|c|}{ Results of urine antigens } \\
\hline Negative & 13,523 & $6147(45.5)$ & $4124(50.1)$ & $2023(38.2)$ & $<0.001$ \\
\hline Any Positive & & $198(1.5)$ & $141(1.7)$ & $57(1.1)$ & \\
\hline Not performed & & 7178 (53.1) & $3962(48.2)$ & 3216 (60.7) & \\
\hline
\end{tabular}

moderate and severe dependence. This may be because we tend to be more cautious in the treatments applied to these groups of patients. Macrolides were more commonly used in men and in those between 40 and 80 years of age. They were less commonly used in patients with previous heart disease such as atrial fibrillation, myocardial infarction, or congestive heart failure. The demographic differences between groups that did and did not receive antibiotics and according to macrolide use are shown in Tables 9 and 10.
Regarding patients' previous treatment, a higher percentage of patients who were taking hydroxychloroquine received antibiotics $(0.6 \%$ vs. $0.1 \% ; p<0.05)$. In the macrolide group, a lower percentage of patients were being treated with systemic corticosteroids (4\% vs. $4.7 \% ; p=0.033)$ and biological therapies (1.1\% vs. $1.6 \%$; $p=0.016$ ) (Tables 11 and 12).

In terms of patients' clinical condition upon admission, the presence of fever $\left(>38{ }^{\circ} \mathrm{C}\right)$, cough, shortness of breath, arthralgia, fatigue, anorexia, and gastrointestinal 
Table 7 Antibiotic therapy used and relationship to mortality (Multivariate analysis adjusted according to patient age and frailty)

\begin{tabular}{lll}
\hline & Odds ratio $(\mathbf{9 5} \% \mathbf{C I})$ & $\boldsymbol{p}$ value \\
\hline Use of antibiotic therapy & $1.52(1.29-1.80)$ & $<0.001$ \\
Age & $1.08(1.08-1.09)$ & $<0.001$ \\
Degree of dependence & & 1 (ref.) \\
Independent or mild & - & $<0.001$ \\
Moderate & $1.78(1.54-2.06)$ & $<0.001$ \\
Severe & $2.05(1.72-2.43)$ & \\
Acquisition of COVID-19 & & 1 (ref.) \\
Community & - & $<0.001$ \\
Nosocomial & $1.71(1.43-2.04)$ & $<0.001$ \\
Nursing Home & $0.66(0.56-0.78)$ & \\
\hline
\end{tabular}

Table 8 Use of macrolides and relationship to mortality (Multivariate analysis adjusted according to patient age and frailty)

\begin{tabular}{lll}
\hline & Odds ratio $\mathbf{9 5 \%} \mathbf{C l})$ & $\boldsymbol{p}$ value \\
\hline Use of macrolides & $0.80(0.73-0.88)$ & $<0.001$ \\
Age & $1.08(1.08-10.9)$ & $<0.001$ \\
Degree of dependence & & 1 (ref.) \\
Independent or mild & - & $<0.001$ \\
Moderate & $1.80(1.56-2.07)$ & $<0.001$ \\
Severe & $2.02(1.70-2.40)$ & \\
Acquisition of COVID-19 & & 1 (ref.) \\
Community & - & $<0.001$ \\
Nosocomial & $1.65(1.38-1.97)$ & $<0.001$ \\
Nursing Home & $0.62(0.53-0.73)$ & \\
\hline
\end{tabular}

symptoms were associated with an increased use of antibiotic therapy. Signs of general illness such as oxygen saturation $<90 \%$, tachypnea, or tachycardia were also associated with increased rates of antibiotic use. Notably relevant is the presence of crackles on lung auscultation in up to $52.6 \%$ of patients. Like rhonchi $(10.8 \%$ of patients), crackles were also associated with antibiotic use. All data on symptoms are shown in Table 13. Regarding the progression of respiratory parameters shown in Tables 14, 15, and 16, significant trends towards improvement were observed between the respiratory parameters on admission and those observed at 1 week in all patients.

\section{Laboratory findings}

Laboratory findings showed an improvement in inflammatory parameters after one week of hospitalization with the exception of procalcitonin and ferritin, which showed no statistically significant changes in either group (general or those receiving antibiotics). Full data are shown in Tables 17 and 18. In the case of interleukin-6, there was a substantial decrease in the total study population after one week (median $30 \mathrm{pg} / \mathrm{mL}$ [IQR $11.4-65$ ] vs. $16 \mathrm{pg} / \mathrm{mL}$ [IQR 4.8-53.6]; $p<0.05$ ), but not in those who received antibiotics (median $31.6 \mathrm{pg} / \mathrm{mL}$ [IQR 11.9-66] vs. $16 \mathrm{pg} / \mathrm{mL}$ [IQR 4.9-56]; $p=0.068$ ). Tables 19 and 20 show the changes at one week after admission in inflammatory parameters in patients who received antibiotics or macrolides.

The decision to start antibiotics was determined by the presence of increased classical inflammatory markers such as C-reactive protein (OR 2.14, 95\% CI $1.91-2.41 ; p<0.05$ ), procalcitonin (OR $1.73,95 \% \mathrm{CI}$ $1.28-2.35 ; p<0.05$ ), or leukocytosis (OR $1.18,95 \% \mathrm{CI}$ $1.01-1.38 ; p<0.05)$. It was also determined by the presence of inflammatory markers associated with COVID19, such as elevated lactate dehydrogenase (OR 1.30, 95\% CI 1.16-1.47; $p<0.05$ ), interleukin-6 (OR 1.73, 95\% CI 1.16-2.59; $p<0.05$ ), or ferritin levels (OR 1.93, 95\% CI $1.59-2.35 ; p<0.05$ ) (Table 21). Table 22 shows the use of different antibiotics according to the previously described laboratory findings, with beta-lactams being the most used antibiotics among all groups.

\section{Radiological findings}

Pulmonary consolidation was present in $48.7 \%$ of patients and interstitial infiltrates in $62.6 \%$. Involvement was mainly bilateral in both groups, particularly in those with interstitial infiltrates (bilateral involvement in $83.5 \%$ of patients with infiltrates). The presence of any kind of infiltrate was linked to antibiotic use ( $p<0.05$; see Table 23). Pleural effusion was present in less than $5 \%$ of patients and was not related to antibiotic use. A thoracic CT scan was performed in 774 patients (5.7\%) and findings compatible with COVID19 were observed in $88.7 \%$ of them; those with compatible findings had increased antibiotic use with (OR 3.53, 95\% CI 1.85-6.73).

Antibiotic use was also related to radiological worsening at one week after admission (OR 1.89; 95\% CI 1.632.20; $p<0.001)$. Statistically significant differences were observed in the presence of pulmonary condensation and interstitial infiltrates at one week after admission in the group which received antibiotics. Changes were also noted in the presence of pleural effusion in the antibiotic group, but the difference was not significant. In the group which received macrolides, the percentage of patients with interstitial infiltrates remained the same, unlike other groups, as can be seen in Tables 24 and 25 . 
Table 9 Demographic data and comorbidities according to use of antibiotic therapy

\begin{tabular}{|c|c|c|c|c|c|}
\hline & Total $(n=13,932)$ & No. (\%) & $\begin{array}{l}\text { With antibiotics } \\
n=12,238 \text { (\%) }\end{array}$ & $\begin{array}{l}\text { Without } \\
\text { antibiotics } \\
n=1498(\%)\end{array}$ & $p$ value \\
\hline Median (IQR) age (years) & & $69(56-80)$ [18-105] & $69(56-79)$ & $67(52-80)$ & $<0.001$ \\
\hline \multicolumn{6}{|l|}{ Age (years) } \\
\hline$<40$ years & 13,736 & $874(6.4)$ & $732(6.0)$ & $142(9.5)$ & 0.002 \\
\hline $40-50$ years & & $1338(9.7)$ & $1143(9.3)$ & $195(13.0)$ & \\
\hline $50-60$ years & & $2175(15.8)$ & $1955(16.0)$ & $220(14.7)$ & \\
\hline $60-70$ years & & 2686 (19.6) & $2442(20.0)$ & $244(16.3)$ & \\
\hline $70-80$ years & & 3277 (23.9) & $2965(24.2)$ & $312(20.8)$ & \\
\hline$>80$ years & & $3386(24.7)$ & $3001(24.5)$ & $385(25.7)$ & \\
\hline \multicolumn{6}{|l|}{ Sex } \\
\hline Women & 13,721 & $5902(43.0)$ & $5137(42.0)$ & $765(51.1)$ & $<0.001$ \\
\hline Men & & $7819(57.0)$ & $7087(58.0)$ & $732(48.9)$ & \\
\hline Hypertension & 13,714 & $6944(50.6)$ & $6261(51.2)$ & $683(45.7)$ & $<0.001$ \\
\hline Diabetes Mellitus & 13,691 & $2617(19.1)$ & $2363(19.4)$ & $254(17.1)$ & 0.034 \\
\hline Dyslipidemia & 13,708 & $5420(39.5)$ & $4888(40.0)$ & $532(35.6)$ & 0.001 \\
\hline Obesity (BMI > 30) & 6,231 & $2102(33.7)$ & $1916(33.9)$ & $186(31.8)$ & 0.30 \\
\hline \multicolumn{6}{|l|}{ Smoking status } \\
\hline Never & 13,077 & $9130(69.8)$ & 8058 (69.2) & $1072(75.1)$ & $<0.001^{*}$ \\
\hline Former & & $3254(24.9)$ & $2995(25.7)$ & $259(18.2)$ & \\
\hline Current & & $693(5.3)$ & $597(5.1)$ & $96(6.7)$ & \\
\hline Alcohol use disorder & 13,270 & $615(4.6)$ & $555(4.7)$ & $60(4.1)$ & 0.33 \\
\hline Atrial fibrillation & 13,704 & $1535(11.2)$ & $1372(11.2)$ & $163(10.9)$ & 0.68 \\
\hline Myocardial infarction & 13,703 & $1091(8.0)$ & $975(8.0)$ & $116(7.8)$ & 0.75 \\
\hline Congestive heart failure & 13,708 & $975(7.1)$ & $850(7.0)$ & $125(8.4)$ & 0.048 \\
\hline Chronic pulmonary disease & 13,710 & $942(6.9)$ & $849(7.0)$ & $93(6.2)$ & 0.29 \\
\hline Chronic bronchitis & 13,708 & $694(5.1)$ & $627(5.1)$ & $67(4.5)$ & 0.28 \\
\hline Asthma & 13,706 & $1002(7.3)$ & $888(7.3)$ & $114(7.6)$ & 0.63 \\
\hline Obstructive sleep apnea syndrome & 13,643 & $832(6.1)$ & $756(6.2)$ & $76(5.1)$ & 0.09 \\
\hline Peripheral vascular disease & 13,701 & $642(4.7)$ & $565(4.6)$ & $77(5.2)$ & 0.37 \\
\hline Dementia & 13,708 & $1384(10.1)$ & $1209(9.9)$ & $175(11.7)$ & 0.029 \\
\hline Cerebrovascular disease & 13,690 & $984(7.2)$ & $864(7.1)$ & $120(8.0)$ & 0.18 \\
\hline Hemiplegia & 13,717 & $225(1.6)$ & $200(1.6)$ & $25(1.7)$ & 0.93 \\
\hline Neurodegenerative disease & 13,713 & $1258(9.2)$ & $1087(8.9)$ & $171(11.4)$ & 0.001 \\
\hline Chronic kidney disease & 13,704 & $821(6.0)$ & $746(6.1)$ & $75(5.0)$ & 0.09 \\
\hline Dialysis & 13,678 & $138(1.0)$ & $123(1.0)$ & $15(1.0)$ & 0.29 \\
\hline Chronic liver disease & 13,675 & $505(3.7)$ & $451(3.7)$ & $54(3.6)$ & 0.89 \\
\hline Cancer & 13,694 & $1113(8.1)$ & $984(8.1)$ & $129(8.6)$ & 0.46 \\
\hline Solid metastatic tumor & 13,704 & $283(2.1)$ & $248(2.0)$ & $35(2.3)$ & 0.43 \\
\hline Leukemia & 13,716 & $167(1.2)$ & $157(1.3)$ & $10(0.7)$ & 0.040 \\
\hline Lymphoma & 13,706 & $194(1.4)$ & $173(1.4)$ & $21(1.4)$ & 0.97 \\
\hline Peptic ulcer & 13,700 & $350(2.6)$ & $310(2.6)$ & $40(2.7)$ & 0.76 \\
\hline Rare disease & 13,673 & $278(2.0)$ & $248(2.0)$ & $30(2.0)$ & 0.95 \\
\hline Rheumatic disease & 13,696 & $318(2.3)$ & $288(2.4)$ & $30(2.0)$ & 0.39 \\
\hline Organ transplantation & 13,563 & $166(1.2)$ & $149(1.2)$ & $17(1.2)$ & 0.81 \\
\hline HIV infection & 13,677 & $94(0.7)$ & $80(0.7)$ & $14(0.9)$ & 0.22 \\
\hline Acquired immunodeficiency syndrome (AIDS) & 13,681 & $40(0.3)$ & $35(0.3)$ & $5(0.3)$ & 0.80 \\
\hline \multicolumn{6}{|l|}{ Degree of dependence } \\
\hline Independent or mild & 13,540 & $11,290(83.4)$ & $10,096(83.7)$ & $1194(81.2)$ & 0.010 \\
\hline Moderate & & $1273(9.4)$ & $1130(9.4)$ & $143(9.7)$ & \\
\hline Severe & & $977(7.2)$ & $843(7.0)$ & $134(9.1)$ & \\
\hline
\end{tabular}


Table 9 (continued)

\begin{tabular}{|c|c|c|c|c|c|}
\hline & Total $(n=13,932)$ & No. (\%) & $\begin{array}{l}\text { With antibiotics } \\
n=12,238(\%)\end{array}$ & $\begin{array}{l}\text { Without } \\
\text { antibiotics } \\
n=1498(\%)\end{array}$ & $p$ value \\
\hline Charlson Comorbidity Index, median (IQR) & 13,373 & $1(0-2)$ & $1(0-2)$ & $1(0-2)$ & 0.84 \\
\hline Age-adjusted Charlson Comorbidity Index, median (IQR) & & $3(2-5)$ & $3(1-5)$ & $3(2-5)$ & 0.08 \\
\hline
\end{tabular}

*Mann-Whitney $U$ test

\section{Treatment and complications}

Most patients received hydroxychloroquine (85.4\%) and/ or lopinavir/ritonavir (62.1\%). In the antibiotic treatment group, more patients received hydroxychloroquine $(87.3 \%$ vs. $70.1 \% ; p<0.001)$, lopinavir/ritonavir $(62.1 \%$ vs. $55 \% ; p<0.001)$, and immunomodulators such as beta interferon, tocilizumab, anakinra, and systemic corticosteroids. The only therapy in which there were no differences between groups was immunoglobulins. All these data are shown in Table 26.

Among the complications developed during hospitalization, higher mortality rates were observed in relation to several factors, including acute respiratory distress syndrome, acute heart failure, arrhythmias, acute kidney failure, shock, and sepsis. Bacterial pneumonia was found in 1481 patients $(10.8 \%)$ and was more frequent among those who received antibiotics (OR 4.85, 95\% CI 3.526.67; $p<0.001)$. Regarding respiratory support, oxygen via high-flow nasal cannula (OR 2.11, 95\% CI 1.63-2.75; $p<0.001$ ), non-invasive mechanical ventilation (OR 3.13 , 95\% CI 2.11-4.66; $p<0.001)$, and invasive mechanical ventilation (OR 4.21, 95\% CI 2.84-6.25; $p<0.001$ ) were used more often in the antibiotic group, as was prone positioning (OR 3.89, 95\% CI 2.87-5.26; $p<0.001$ ). A higher percentage of patients in the antibiotic group was transferred to intensive care units (ICU) compared to those who did not receive antibiotics (Table 27).

The median length of hospital stay was eight days (IQR 5-13). The death rate in the group that received antibiotics was $21.2 \%$ and the death rate in the group that did not receive antibiotics was $16.2 \%$ (OR 1.40, 95\% CI 1.21-1.62; $p<0.001)$. Ninety-four percent of the deaths were directly caused by COVID-19, with the remaining $6 \%$ occurring due to other reasons. Just $3.8 \%$ of patients were readmitted at a median time of 9 days after discharge (IQR 3-17); in $58.7 \%$ of these cases, readmission was unrelated to COVID-19. All these data are shown in Table 28.

Tables 29 and 30 show the multivariate statistical analysis of the relationship between the use of antibiotic therapy and macrolides and mortality, adjusted for relevant clinical and analytical variables. We have chosen the procalcitonin level cut-off of $0.15 \mathrm{ng} / \mathrm{mL}$ as it has the best sensitivity and specificity profile after analysis using ROC curves. After statistical adjustment in the multivariate analysis, the use of antibiotic therapy is not statistically significantly related to a reduction in mortality (OR 1.20 , 95\% CI 0.94-1.53, $\mathrm{p}=0.14)$. On the other hand, the use of azithromycin is associated with a lower odds of death (OR 0.64, 95\% CI 0.56-0.73, p<0.001).

\section{Discussion}

Since the start of the COVID-19 pandemic, efforts have been made to show the role that antibiotics associated with antivirals, anti-inflammatories, and other immunomodulatory drugs may play in order to define an effective therapy against COVID- 19 .

Some authors think that the difficulty in finding antiviral treatments with proven efficacy along with the anxiety and uncertainty that this generates in physicians has likely led to the uncontrolled prescription of antibiotic therapy in patients worldwide [26]. Indeed, emerging data show that more than $90 \%$ of COVID-19 patients receive antibacterial drugs [27, 28].

In the Chinese city of Wuhan, where the pandemic started, most patients with COVID-19 seem to have received empiric antibiotic therapy, mostly respiratory fluoroquinolones [29]. The use of antifungal drugs and corticosteroids was more limited. Similar data are described in other studies in China, revealing use of antibiotic therapy in more than half of hospitalized patients [30-33].

In the United States of America, the strategy for empiric antibiotic therapy has been along these same lines. More prevalent antibiotic use was revealed in ICU patients, where $94.9 \%(224 / 236)$ were on antibiotics [34]. In another series in Detroit, antibiotic use in $69.2 \%$ (148 of 214 patients) of patients admitted to the conventional ward was documented; their study population had baseline characteristics that were similar to ours [35].

Langford et al. have conducted a rapid systematic review that determined that the majority of patients with COVID-19 received antibiotics (71.8\%, 95\% CI 56.1-87.7). The most common were broad-spectrum antibiotics, with fluoroquinolones and third-generation cephalosporins representing $74 \%$ of the antibiotics prescribed [36]. 
Table 10 Demographic data and comorbidities according to use of macrolides

\begin{tabular}{|c|c|c|c|c|c|}
\hline & Total $(n=13,932)$ & No. (\%) & $\begin{array}{l}\text { With macrolides } \\
n=8382(\%)\end{array}$ & $\begin{array}{l}\text { Without } \\
\text { macrolides } \\
n=5502(\%)\end{array}$ & $p$ value \\
\hline Median (IQR) age (years) & & $69(56-80)$ [18-105] & $68(56-79)$ & $71(57-82)$ & $<0.001$ \\
\hline \multicolumn{6}{|l|}{ Age (years) } \\
\hline$<40$ years & 13,884 & $882(6.4)$ & $483(5.8)$ & $399(7.3)$ & $<0.001^{*}$ \\
\hline $40-50$ years & & $1359(9.8)$ & $843(10.1)$ & $516(9.4)$ & \\
\hline $50-60$ years & & $2199(15.8)$ & $1418(16.9)$ & $781(14.2)$ & \\
\hline $60-70$ years & & 2708 (19.5) & $1756(21.0)$ & $952(17.3)$ & \\
\hline $70-80$ years & & $3318(23.9)$ & $2024(24.15)$ & $1294(23.5)$ & \\
\hline$>80$ years & & $3418(24.6)$ & $1858(22.2)$ & $1560(28.4)$ & \\
\hline \multicolumn{6}{|l|}{ Sex } \\
\hline Women & 13,869 & $5953(42.9)$ & $3464(41.4)$ & $2489(45.3)$ & $<0.001$ \\
\hline Men & & 7916 (57.1) & $4912(58.6)$ & $3004(54.7)$ & \\
\hline Hypertension & 13,862 & 7010 (50.6) & $4223(50.5)$ & $2787(50.8)$ & 0.74 \\
\hline Diabetes Mellitus & 13,838 & $2645(19.1)$ & $1550(18.5)$ & $1095(20.0)$ & 0.033 \\
\hline Dyslipidemia & 13,856 & $5479(39.5)$ & $3326(39.8)$ & $2153(39.2)$ & 0.53 \\
\hline Obesity (BMI > 30) & 6287 & $2128(33.9)$ & $1387(35.4)$ & $741(31.3)$ & 0.001 \\
\hline \multicolumn{6}{|l|}{ Smoking status } \\
\hline Never & 13,214 & $9212(69.7)$ & $5522(68.9)$ & $3690(71.0)$ & 0.021 \\
\hline Former & & $3299(25.0)$ & $2083(26.0)$ & $1216(23.4)$ & \\
\hline Current & & $703(5.3)$ & $413(5.2)$ & $290(5.6)$ & \\
\hline Alcohol use disorder & 13,412 & $624(4.7)$ & $380(4.7)$ & $244(4.6)$ & 0.82 \\
\hline Atrial fibrillation & 13,851 & $1552(11.2)$ & $837(10.0)$ & $715(13.0)$ & $<0.001$ \\
\hline Myocardial infarction & 13,849 & $1103(8.0)$ & $625(7.5)$ & $478(8.7)$ & 0.009 \\
\hline Congestive heart failure & 13,855 & $988(7.1)$ & $518(6.2)$ & $470(8.6)$ & $<0.001$ \\
\hline Chronic pulmonary disease & 13,856 & $948(6.8)$ & $519(6.2)$ & $429(7.8)$ & $<0.001$ \\
\hline Chronic bronchitis & 13,855 & $703(5.1)$ & $424(5.1)$ & $279(5.1)$ & 0.96 \\
\hline Asthma & 13,853 & $1010(7.3)$ & $623(7.5)$ & $387(7.1)$ & 0.38 \\
\hline Obstructive sleep apnea syndrome & 13,791 & $846(6.1)$ & $549(6.6)$ & $297(5.4)$ & 0.006 \\
\hline Peripheral vascular disease & 13,848 & $652(4.7)$ & $383(4.6)$ & $269(4.9)$ & 0.39 \\
\hline Dementia & 13,852 & $1392(10.1)$ & $691(8.3)$ & $701(12.8)$ & $<0.001$ \\
\hline Cerebrovascular disease & 13,837 & $994(7.2)$ & $553(6.6)$ & $441(8.0)$ & 0.002 \\
\hline Hemiplegia & 13,863 & $228(1.6)$ & $119(1.4)$ & $109(2.0)$ & 0.011 \\
\hline Neurodegenerative disease & 13,860 & $1268(9.2)$ & $610(7.3)$ & $658(12.0)$ & $<0.001$ \\
\hline Chronic kidney disease & 13,851 & $828(6.0)$ & $493(5.9)$ & $335(6.1)$ & 0.62 \\
\hline Dialysis & 13,826 & $140(1.0)$ & $78(0.9)$ & $62(1.1)$ & 0.011 \\
\hline Chronic liver disease & 13,821 & $511(3.7)$ & $298(3.6)$ & $213(3.9)$ & 0.33 \\
\hline Cancer & 13,842 & $1128(8.2)$ & $602(7.2)$ & $526(9.6)$ & $<0.001$ \\
\hline Solid metastatic tumor & 13,852 & $284(2.1)$ & $147(1.8)$ & $137(2.5)$ & 0.003 \\
\hline Leukemia & 13,864 & $169(1.2)$ & $107(1.3)$ & $62(1.1)$ & 0.43 \\
\hline Lymphoma & 13,854 & $198(1.4)$ & $94(1.1)$ & $104(1.9)$ & $<0.001$ \\
\hline Peptic ulcer & 13,848 & $353(2.6)$ & $208(2.5)$ & 145 (2.6) & 0.58 \\
\hline Rare disease & 13,821 & $280(2.0)$ & $133(1.6)$ & $147(2.7)$ & $<0.001$ \\
\hline Rheumatic disease & 13,844 & $321(2.3)$ & $184(2.2)$ & $137(2.5)$ & 0.26 \\
\hline Organ transplantation & 13,708 & $170(1.2)$ & $97(1.2)$ & $73(1.4)$ & 0.37 \\
\hline HIV infection & 13,825 & $97(0.7)$ & $55(0.7)$ & $42(0.8)$ & 0.46 \\
\hline Acquired immunodeficiency syndrome (AIDS) & 13,828 & $40(0.3)$ & $26(0.3)$ & $14(0.3)$ & 0.55 \\
\hline \multicolumn{6}{|l|}{ Degree of dependence } \\
\hline Independent or mild & 13,680 & $11,415(83.4)$ & $7093(85.8)$ & $4322(79.9)$ & $<0.001$ \\
\hline Moderate & & $1283(9.4)$ & $703(8.5)$ & $580(10.7)$ & \\
\hline Severe & & $982(7.2)$ & $473(5.7)$ & $509(9.4)$ & \\
\hline
\end{tabular}


Table 10 (continued)

\begin{tabular}{|c|c|c|c|c|c|}
\hline & Total $(n=13,932)$ & No. (\%) & $\begin{array}{l}\text { With macrolides } \\
\mathrm{n}=8382(\%)\end{array}$ & $\begin{array}{l}\text { Without } \\
\text { macrolides } \\
n=5502(\%)\end{array}$ & $p$ value \\
\hline Charlson Comorbidity Index, median (IQR) & 13,511 & $1(0-2)$ & $1(0-2)$ & $1(0-2)$ & $<0.001$ \\
\hline Age-adjusted Charlson Comorbidity Index, median (IQR) & & $3(2-5)$ & $3(1-5)$ & $4(2-6)$ & $<0.001$ \\
\hline
\end{tabular}

*Mann-Whitney U test

Table 11 Use of antibiotic therapy according to habitual treatment

\begin{tabular}{|c|c|c|c|c|c|}
\hline & Total $(n=13,932)$ & No. (\%) & $\begin{array}{l}\text { With antibiotics } \\
n=12,238(\%)\end{array}$ & $\begin{array}{l}\text { Without antibiotics } \\
n=1498(\%)\end{array}$ & $p$ value \\
\hline Highly active antiretroviral therapy (HAART) & 13,706 & $91(0.7)$ & $79(0.7)$ & $12(0.8)$ & 0.49 \\
\hline Metformin & 13,713 & $1873(13.7)$ & $1690(13.8)$ & $183(12.2)$ & 0.09 \\
\hline Systemic corticosteroids & 13,703 & $583(4.3)$ & $525(4.3)$ & $58(3.9)$ & 0.44 \\
\hline Inhaled corticosteroids & 13,663 & $1296(9.5)$ & $1173(9.6)$ & $123(8.3)$ & 0.09 \\
\hline Hydroxychloroquine & 13,707 & $69(0.5)$ & $67(0.6)$ & $2(0.1)$ & 0.032 \\
\hline Rapamycin (sirolimus) & 13,675 & $62(0.5)$ & $57(0.5)$ & $5(0.3)$ & 0.68 \\
\hline Immunosuppressants & 13,689 & $477(3.5)$ & $433(3.6)$ & $44(3.0)$ & 0.23 \\
\hline Biological therapy (monoclonal antibodies) & 13,703 & $177(1.3)$ & $155(1.3)$ & $22(1.5)$ & 0.52 \\
\hline
\end{tabular}

Table 12 Use of macrolides according to habitual treatment

\begin{tabular}{|c|c|c|c|c|c|}
\hline & Total $(n=13,932)$ & No. (\%) & $\begin{array}{l}\text { With macrolides } \\
\mathrm{n}=8382(\%)\end{array}$ & $\begin{array}{l}\text { Without macrolides } \\
\mathrm{n}=5502(\%)\end{array}$ & $p$ value \\
\hline Highly active antiretroviral therapy (HAART) & 13,853 & $93(0.7)$ & $57(0.7)$ & $36(0.7)$ & 0.86 \\
\hline Metformin & 13,860 & $1890(13.6)$ & $1154(13.8)$ & $736(13.4)$ & 0.51 \\
\hline Systemic corticosteroids & 13,849 & $591(4.3)$ & $332(4.0)$ & $259(4.7)$ & 0.033 \\
\hline Inhaled corticosteroids & 13,808 & $1304(9.4)$ & 796 (9.6) & $508(9.3)$ & 0.61 \\
\hline Hydroxychloroquine & 13,855 & $70(0.5)$ & $51(0.6)$ & $19(0.4)$ & 0.033 \\
\hline Rapamycin (sirolimus) & 13,820 & $63(0.5)$ & $41(0.5)$ & $22(0.4)$ & 0.44 \\
\hline Immunosuppressants & 13,836 & $486(3.5)$ & $278(3.3)$ & $208(3.8)$ & 0.14 \\
\hline Biological therapy (monoclonal antibodies) & 13,851 & $180(1.3)$ & $93(1.1)$ & $87(1.6)$ & 0.016 \\
\hline
\end{tabular}

The work by Beovic et al. consisted of a survey aimed at doctors in Europe. As was the case in Asia and America, the study revealed indiscriminate use of broad-spectrum antibiotic therapy. In particular, the study highlights that Spain is one of the countries with the highest rates of antibiotic use-only $22.7 \%$ of patients with COVID-19 in the conventional ward were not routinely prescribed antibiotics-behind only Italy (18.2\%) and Turkey (19.6\%) [37].

\section{What causes the indiscriminate use of empiric antibiotic therapy in COVID-19 patients?}

Antibiotics are usually prescribed in light of the possibility that these patients may have a bacterial infection associated with the ailment that is either concomitant with the initial viral infection or in relation to an extended hospital stay [38, 39].

It is known that bacteria (especially Streptococcus pneumoniae and Staphylococcus aureus) as well as other viral or fungal co-infections are frequent complications that occur in seasonal influenza outbreaks which contribute to increased morbidity and mortality in these patients [40-42]. Previous studies have documented that fatality associated with viral pneumonias may be influenced by multiple factors, one of the most prominent being bacterial co-infection $[43,44]$. In fact, most bacterial coinfections linked to a primary viral infection are seen in influenza cases [45]. Several studies from the USA and Australia found that in the $2009 \mathrm{H} 1 \mathrm{~N} 1$ flu pandemic, $4-33 \%$ of patients hospitalized due to that disease had bacterial pneumonia [45-49]. 
Table 13 Use of antibiotic therapy according to initial clinical condition

\begin{tabular}{|c|c|c|c|c|c|}
\hline & Total $(n=13,932)$ & No. (\%) & $\begin{array}{l}\text { With antibiotics } \\
n=12,238(\%)\end{array}$ & $\begin{array}{l}\text { Without antibiotics } \\
n=1498(\%)\end{array}$ & $p$ value \\
\hline \multicolumn{6}{|l|}{ Symptoms } \\
\hline Time from onset of symptoms, median (IQR) & 13,576 & $6(3-9)$ & $7(4-9)$ & $6(2-8)$ & $<0.001$ \\
\hline \multicolumn{6}{|l|}{ Fever } \\
\hline $\mathrm{No}\left(<37^{\circ} \mathrm{C}\right)$ & 13,692 & $2137(15.6)$ & $1778(14.6)$ & $359(24.0)$ & $<0.001$ \\
\hline Low-grade fever $\left(37-37.9^{\circ} \mathrm{C}\right)$ & & $2865(20.9)$ & $2487(20.4)$ & $378(25.3)$ & \\
\hline Fever $\left(>38^{\circ} \mathrm{C}\right)$ & & $8690(63.5)$ & $7932(65.0)$ & $758(50.7)$ & \\
\hline Shortness of breath & 13,677 & $7879(57.6)$ & $7182(58.9)$ & $697(46.8)$ & $<0.001$ \\
\hline Sore throat & 13,504 & $1294(9.6)$ & $1137(9.5)$ & $157(10.6)$ & 0.16 \\
\hline \multicolumn{6}{|l|}{ Cough } \\
\hline No & 13,689 & $3600(26.3)$ & $3106(25.5)$ & $494(33.1)$ & $<0.001$ \\
\hline Dry & & $7957(58.1)$ & $7132(58.5)$ & $825(55.3)$ & \\
\hline Productive & & $2132(15.6)$ & $1958(16.1)$ & $174(11.7)$ & \\
\hline Arthralgia & 13,568 & $4073(30.0)$ & 3695 (30.6) & $378(25.6)$ & $<0.001$ \\
\hline Fatigue & 13,533 & $5875(43.4)$ & $5346(44.4)$ & $529(35.7)$ & $<0.001$ \\
\hline Anorexia & 13,471 & 2634 (19.6) & $2415(20.1)$ & $219(14.8)$ & $<0.001$ \\
\hline Ageusia & 13,352 & $1002(7.5)$ & $910(7.7)$ & $92(6.3)$ & 0.06 \\
\hline Anosmia & 13,345 & $892(6.7)$ & $804(6.8)$ & $88(6.0)$ & 0.27 \\
\hline Headache & 13,516 & $1531(11.3)$ & $1364(11.3)$ & $167(11.3)$ & 0.97 \\
\hline Nausea & 13,460 & $1648(12.2)$ & $1499(12.5)$ & $149(10.2)$ & 0.011 \\
\hline Vomiting & 13,572 & $992(7.3)$ & $906(7.5)$ & $86(5.8)$ & 0.020 \\
\hline Diarrhea & 13,617 & $3174(23.3)$ & $2885(23.8)$ & $289(19.5)$ & $<0.001$ \\
\hline Abdominal pain & 13,566 & $867(6.4)$ & $776(6.4)$ & $91(6.2)$ & 0.70 \\
\hline \multicolumn{6}{|l|}{ Vital signs } \\
\hline Confusion & 13,576 & $1614(11.9)$ & $1451(12.0)$ & $163(11.1)$ & 0.33 \\
\hline \multicolumn{6}{|l|}{ Temperature } \\
\hline Fever $\left(>38^{\circ} \mathrm{C}\right)$ & 13,254 & 2105 (15.9) & $1911(16.1)$ & $194(13.7)$ & 0.019 \\
\hline Median $(\mathrm{IQR}){ }^{\circ} \mathrm{C}$ & & $37.0(36.4-37.8)$ & $37.0(36.4-37.8)$ & $36.8(36.3-37.7)$ & $<0.001$ \\
\hline \multicolumn{6}{|l|}{ Oxygen saturation \% } \\
\hline$<90 \%$ & 13,316 & $2987(22.4)$ & $2783(23.4)$ & $204(14.3)$ & $<0.001$ \\
\hline Median (IQR) SatO2\% & & $94(91-97)$ & $94(91-96)$ & $96(93-97)$ & $<0.001$ \\
\hline Tachypnea (> 20 breaths/min) & 13,360 & $4,126(30.9)$ & $3772(31.7)$ & $354(24.4)$ & $<0.001$ \\
\hline \multicolumn{6}{|l|}{ Heart rate } \\
\hline Tachycardia (> 100 beats/min) & 13,254 & 2965 (22.4) & $2681(22.6)$ & $284(20.2)$ & 0.035 \\
\hline Median (IQR) & & $87(76-100)$ & $87(77-100)$ & $85(74-98)$ & $<0.001$ \\
\hline SBP, median (IQR) mmHg & 13,093 & $127(114-141)$ & $127(114-141)$ & $128(115-140)$ & 0.20 \\
\hline DBP, median (IQR) mmHg & & $73(65-81)$ & $73(65-81)$ & $74(65-82)$ & 0.67 \\
\hline \multicolumn{6}{|l|}{ Lung auscultation } \\
\hline Crackles & 13,357 & 7029 (52.6) & $6434(54.0)$ & $595(41.3)$ & $<0.001$ \\
\hline Wheezing & 13,353 & $811(6.1)$ & $725(6.1)$ & $86(6.0)$ & 0.86 \\
\hline Rhonchi & 13,344 & $1442(10.8)$ & $1319(11.1)$ & $123(8.5)$ & 0.003 \\
\hline
\end{tabular}

Co-infection by bacteria and viruses in respiratory infections is not only restricted to influenza. Similar conditions have also been reported in other respiratory viruses such as the parainfluenza virus, respiratory syncytial virus, adenovirus, rhinovirus, human metapneumovirus, and even in pathogens similar to SARS-CoV-2 such as SARS (Severe Acute respiratory syndrome) and MERS (Middle-East respiratory syndrome) [50-53].

Nevertheless, the current evidence on SARS-CoV-2 indicates that the risk of bacterial co-infection upon admission is minimal, though risk increases progressively during hospitalization and critical patients are at highest risk [54]. In several studies conducted in China and Italy, 
Table 14 Clinical outcomes in total population

\begin{tabular}{|c|c|c|c|c|c|c|}
\hline $\begin{array}{l}\text { On admission } \\
\text { Oxygen saturation \% }\end{array}$ & Total $(n=13,932)$ & No. (\%) & $\begin{array}{l}1 \text { week after admission } \\
\text { Oxygen saturation \% }\end{array}$ & Total $(n=13,932)$ & No. (\%) & $p$ value \\
\hline$<90 \%$ & 13,493 & 3025 (22.4) & $<90 \%$ & 11,467 & $1525(13.3)$ & $<0.001$ \\
\hline Median (IQR) SatO2\% & & $94(91-97)$ & Median (IQR) SatO2\% & & $95(93-97)$ & $<0.001$ \\
\hline $\mathrm{pH}$ in arterial blood & 7096 & $7.45(7.41-7.48)$ & $\mathrm{pH}$ in arterial blood & 2838 & $7.42(7.37-7.46)$ & $<0.001$ \\
\hline pCO2 & 7180 & $34(31-39)$ & $\mathrm{pCO} 2$ & 2859 & $40(35-46)$ & $<0.001$ \\
\hline pO2 & 6827 & $66(56-78)$ & pO2 & 2761 & $73(60-91)$ & $<0.001$ \\
\hline $\mathrm{pO} 2 / \mathrm{FiO} 2 \mathrm{mmHg}$ & 6540 & $289(233-342)$ & $\mathrm{pO} 2 / \mathrm{FiO} 2 \mathrm{mmHg}$ & 2597 & $229(120-328)$ & $<0.001$ \\
\hline
\end{tabular}

Table 15 Clinical outcomes among those who received antibiotics

\begin{tabular}{|c|c|c|c|c|c|c|}
\hline On admission & Total $(n=13,736)$ & No. (\%) & 1 week after admission & $\begin{array}{l}\text { No. (Total } \\
n=13,736)\end{array}$ & No. (\%) & $p$ value \\
\hline Oxygen saturation $\%$ & & & Oxygen saturation \% & & & \\
\hline$<90 \%$ & 13,316 & $2783(23.4)$ & $<90 \%$ & 11,339 & $1407(13.8)$ & $<0.001$ \\
\hline Median (IQR) SatO2\% & & $94(91-96)$ & Median (IQR) SatO2\% & & $95(93-97)$ & $<0.001$ \\
\hline pH in arterial blood & 6504 & $7.45(7.41-7.48)$ & $\mathrm{pH}$ in arterial blood & 2608 & $7.42(7.38-7.46)$ & $<0.001$ \\
\hline $\mathrm{pCO} 2$ & 6577 & $34(31-39)$ & $\mathrm{pCO} 2$ & 2622 & $40(35-46)$ & $<0.001$ \\
\hline $\mathrm{pO} 2$ & 6288 & $66(56-77)$ & $\mathrm{pO} 2$ & 2543 & $73(60-90)$ & $<0.001$ \\
\hline $\mathrm{pO} 2 / \mathrm{FiO} 2 \mathrm{mmHg}$ & 6026 & $288(233-343)$ & $\mathrm{pO} 2 / \mathrm{FiO} 2 \mathrm{mmHg}$ & 2400 & $223(119-325)$ & $<0.001$ \\
\hline
\end{tabular}

Table 16 Clinical outcomes among those who received macrolides

\begin{tabular}{|c|c|c|c|c|c|c|}
\hline $\begin{array}{l}\text { On admission } \\
\text { Oxygen saturation \% }\end{array}$ & Total $(n=13,884)$ & No. (\%) & $\begin{array}{l}1 \text { week after admission } \\
\text { Oxygen saturation } \%\end{array}$ & Total $(n=13,884)$ & No. (\%) & $p$ value \\
\hline$<90 \%$ & 13,454 & $3,020(22.5)$ & $<90 \%$ & 11,439 & $914(12.9)$ & $<0.001$ \\
\hline Median (IQR) SatO2\% & & $94(91-96)$ & Median (IQR) SatO2\% & & $95(93-97)$ & $<0.001$ \\
\hline $\mathrm{pH}$ in arterial blood & 4721 & $7.45(7.41-7.48)$ & $\mathrm{pH}$ in arterial blood & 1997 & $7.43(7.38-7.46)$ & $<0.001$ \\
\hline $\mathrm{pCO} 2$ & 4785 & $34(31-38)$ & $\mathrm{pCO} 2$ & 2017 & $40(35-45)$ & $<0.001$ \\
\hline pO2 & 4578 & $66(56-77)$ & pO2 & 1957 & $74(61-91)$ & $<0.001$ \\
\hline $\mathrm{pO} 2 / \mathrm{FiO} 2 \mathrm{mmHg}$ & 4380 & $290(235-343)$ & $\mathrm{pO} 2 / \mathrm{FiO} 2 \mathrm{mmHg}$ & 1844 & 223 (124-333) & $<0.001$ \\
\hline
\end{tabular}

rates of bacterial infection of $<10 \%$ were found $[55,57]$. In a meta-analysis by Langford et al., in which a total of 1308 publications were reviewed with 24 studies included in the final statistical analysis, the presence of bacterial infection was assessed in 3338 patients and found in 281 of them (8.4\%) [36].

Although the actual prevalence of bacterial infection in patients with SARS-CoV-2 pneumonia has not been fully demonstrated and further studies are needed, several clinical guidelines advocate for using empiric antibiotic therapy in patients with COVID-19, especially in critically ill patients $[58,59]$. Many guidance documents recommend antibiotic treatment for patients with COVID-19 and 'pneumonia' [60].
In the survey of European doctors carried out by Beovic et al., nearly two-thirds of participants reported that they did indeed have local guidelines regarding antibiotic use in patients with COVID-19 [37], but more often than not, they followed their hospital's community-acquired pneumonia guidelines [15]. Most professionals opted for coverage of pathogens that cause atypical pneumonia. However, these guidelines appear to be grounded in the experience gained in studies of co-infection in patients with influenza, in which the majority were caused by Streptococcus pneumoniae and Staphylococcus aureus [61]. In light of this, several authors recommend that if antibiotics are considered, a beta-lactam providing coverage for $S$. pneumoniae \pm methicillin-susceptible $S$. aureus should be the first [26]. In contrast, other 
Table 17 Laboratory findings in total population

\begin{tabular}{|c|c|c|c|c|c|c|}
\hline On admission & No & Median (IQR) & 1 week after admission & No & Median (IQR) & $p$ value \\
\hline Hemoglobin (g/dL) & 13,622 & $13.9(12.6-15)$ & Hemoglobin (g/dL) & 12,646 & $13(11.8-14.1)$ & $<0.001$ \\
\hline Platelet count $\left(\times 10^{6} / \mathrm{L}\right)$ & 13,636 & $190,000(148,000-246,000)$ & Platelet count $\left(\times 10^{\wedge} \sigma / L\right)$ & 12,631 & $275,000(199,000-371,000)$ & $<0.001$ \\
\hline Leukocytes $\left(\times 10^{6} / \mathrm{L}\right)$ & 13,620 & $6300(4770-8,500)$ & Leukocytes $(\times 10 \wedge 6 / L)$ & 12,644 & $6500(4900-9000)$ & $<0.001$ \\
\hline Neutrophils (× 106/L) & 13,558 & $4590(3200-6700)$ & Neutrophils $\left(\times 10^{\wedge} 6 / L\right)$ & 12,594 & $4325(2900-6900)$ & 0.025 \\
\hline Lymphocytes $\left(\times 10^{6} / \mathrm{L}\right)$ & 13,613 & $940(690-1300)$ & Lymphocytes (× 10^6/L) & 12,626 & $1108(700-1600)$ & $<0.001$ \\
\hline C-reactive protein (mg/L) & 13,127 & $59.1(18.91-127)$ & C-reactive protein $(\mathrm{mg} / \mathrm{L})$ & 12,248 & $23.5(7-74.1)$ & $<0.001$ \\
\hline Procalcitonin $(\mathrm{ng} / \mathrm{mL})$ & 6452 & $0.1(0.05-0.22)$ & Procalcitonin (ng/mL) & 4907 & $0.09(0.04-0.2)$ & 0.061 \\
\hline Ferritin $(\mathrm{mcg} / \mathrm{mL})$ & 5325 & $606(291-1221)$ & Ferritin $(\mathrm{mcg} / \mathrm{mL})$ & 6149 & $653(337-1217)$ & 0.36 \\
\hline Fibrinogen (mg/dL) & 8789 & $610(500-730)$ & Fibrinogen (mg/dL) & 7852 & $573(467-701)$ & $<0.001$ \\
\hline Interleukin-6 [IL-6] (pg/mL) & 1767 & $30(11.36-65)$ & Interleukin-6 [lL-6] (pg/mL) & 2074 & $16(4.8-53.6)$ & 0.045 \\
\hline Creatine kinase $[C K](U / L)$ & 6844 & $91(54-174)$ & Creatine kinase $[\mathrm{CK}](\mathrm{U} / \mathrm{L})$ & 5775 & $54(33-104)$ & $<0.001$ \\
\hline $\begin{array}{l}\text { Lactate dehydrogenase }[\mathrm{LDH}] \\
(\mathrm{mg} / \mathrm{dL})\end{array}$ & 11,825 & $317(245-428)$ & $\begin{array}{l}\text { Lactate dehydrogenase [LDH] } \\
\text { (mg/dL) }\end{array}$ & 11,264 & $283(219-402)$ & $<0.001$ \\
\hline D-Dimer (ng/dL) & 10,590 & $660(372-1220)$ & D-Dimer (ng/dL) & 9605 & $714(384-1470)$ & $<0.001$ \\
\hline Creatinine (mg/dL) & 13,586 & $0.9(0.73-1.16)$ & Creatinine (mg/dL) & 12,599 & $0.82(0.68-1.05)$ & $<0.001$ \\
\hline Albumin (g/dL) & 5717 & $3.8(3.4-4.1)$ & Albumin (g/dL) & 5358 & $3.4(3.1-3.8)$ & $<0.001$ \\
\hline Bilirubin (mg/dL) & 10,296 & $0.5(0.4-0.7)$ & Bilirubin (mg/dL) & 9458 & $0.6(0.4-0.89)$ & $<0.001$ \\
\hline $\begin{array}{l}\text { Alanine aminotransferase [GPT- } \\
\text { ALT] (U/L) }\end{array}$ & 12,786 & $29(19-46)$ & $\begin{array}{l}\text { Alanine aminotransferase [GPT- } \\
\text { ALT] (U/L) }\end{array}$ & 11,815 & $36(22-64)$ & $<0.001$ \\
\hline $\begin{array}{l}\text { Aspartate Aminotransferase } \\
\text { [GOT-AST] (U/L) }\end{array}$ & 10,708 & $35(25-52)$ & $\begin{array}{l}\text { Aspartate Aminotransferase } \\
\text { [GOT-AST] (U/L) }\end{array}$ & 10,551 & $34(23-53)$ & 0.14 \\
\hline
\end{tabular}

Table 18 Laboratory findings among those who received antibiotics

\begin{tabular}{|c|c|c|c|c|c|c|}
\hline On admission & No & Median (IQR) & 1 week after admission & No & Median (IQR) & $\overline{p \text { value }}$ \\
\hline Hemoglobin (g/dL) & 12,188 & $13.9(12.6-15)$ & Hemoglobin (g/dL) & 11,394 & $13(11.8-14.1)$ & $<0.001$ \\
\hline Platelet count $\left(\times 10^{6} / \mathrm{L}\right)$ & 12,193 & $189,000(148,000-246,000)$ & Platelet count $\left(\times 10^{6} / \mathrm{L}\right)$ & 11,382 & $278,000(200,000-374,000)$ & $<0.001$ \\
\hline Leukocytes (× 106/L) & 12,186 & $6300(4770-8500)$ & Leukocytes $\left(\times 10^{6} / \mathrm{L}\right)$ & 11,394 & $6560(4950-9100)$ & $<0.001$ \\
\hline Neutrophils $\left(\times 10^{6} / \mathrm{L}\right)$ & 12,130 & $4600(3230-6750)$ & Neutrophils (× 106/L) & 11,352 & $4400(2950-7070)$ & 0.010 \\
\hline Lymphocytes (× 106/L) & 12,172 & $920(680-1,300)$ & Lymphocytes $\left(\times 10^{6} / \mathrm{L}\right)$ & 11,380 & $1100(700-1590)$ & $<0.001$ \\
\hline C-reactive protein (mg/L) & 11,754 & $63(21-131)$ & C-reactive protein (mg/L) & 11,061 & $24.2(7.1-77.5)$ & $<0.001$ \\
\hline Procalcitonin (ng/mL) & 5812 & $0.1(0.06-0.23)$ & Procalcitonin (ng/mL) & 4411 & $0.09(0.05-0.21)$ & 0.18 \\
\hline Ferritin $(\mathrm{mcg} / \mathrm{mL})$ & 4821 & $627(305-1,246)$ & Ferritin $(\mathrm{mcg} / \mathrm{mL})$ & 5519 & $665(346-1249)$ & 0.20 \\
\hline Fibrinogen (mg/dL) & 7867 & $611(500-737)$ & Fibrinogen (mg/dL) & 7021 & $573(470-708)$ & $<0.001$ \\
\hline Interleukin-6 [IL-6] (pg/mL) & 1583 & $31.6(11.9-66)$ & Interleukin-6 [IL-6] (pg/mL) & 1856 & $16(4.86-56)$ & 0.068 \\
\hline Creatine kinase $[\mathrm{CK}](\mathrm{U} / \mathrm{L})$ & 6262 & $92(55-175)$ & Creatine kinase $[\mathrm{CK}](\mathrm{U} / \mathrm{L})$ & 5309 & $54(33-105)$ & $<0.001$ \\
\hline $\begin{array}{l}\text { Lactate dehydrogenase [LDH] } \\
(\mathrm{mg} / \mathrm{dL})\end{array}$ & 10,618 & $320(247-430)$ & $\begin{array}{l}\text { Lactate dehydrogenase [LDH] } \\
\text { (mg/dL) }\end{array}$ & 10,151 & $285(220-406)$ & $<0.001$ \\
\hline D-Dimer (ng/dL) & 9508 & $667(380-1226)$ & D-Dimer (ng/dL) & 8624 & 732 (395-1506) & $<0.001$ \\
\hline Creatinine (mg/dL) & 12,156 & $0.91(0.70-1.21)$ & Creatinine (mg/dL) & 11,366 & $0.83(0.68-1.05)$ & $<0.001$ \\
\hline Albumin (g/dL) & 5199 & $3.8(3.4-4.1)$ & Albumin $-(\mathrm{g} / \mathrm{dL})$ & 4853 & $3.4(3.1-3.8)$ & $<0.001$ \\
\hline Bilirubin (mg/dL) & 9259 & $0.5(0.4-0.7)$ & Bilirubin (mg/dL) & 8586 & $0.59(0.40-0.87)$ & $<0.001$ \\
\hline $\begin{array}{l}\text { Alanine aminotransferase [GPT- } \\
\text { ALT] (U/L) }\end{array}$ & 11,515 & $29(19-47)$ & $\begin{array}{l}\text { Alanine aminotransferase [GPT- } \\
\text { ALT] (U/L) }\end{array}$ & 10,730 & $37(22-66)$ & $<0.001$ \\
\hline $\begin{array}{l}\text { Aspartate Aminotransferase } \\
\text { [GOT-AST] (U/L) }\end{array}$ & 9519 & $36(26-53)$ & $\begin{array}{l}\text { Aspartate Aminotransferase } \\
\text { [GOT-AST] (U/L) }\end{array}$ & 9466 & $34(23-54)$ & 0.14 \\
\hline
\end{tabular}


Table 19 Laboratory outcomes after using antibiotics

\begin{tabular}{|c|c|c|c|c|c|c|}
\hline 1 WEEK AFTER ADMISSION & $\begin{array}{l}\text { No. (Total } \\
n=13,932)\end{array}$ & No. (\%) & $\begin{array}{l}\text { WITH antibiotics } \\
n=12,238(\%)\end{array}$ & $\begin{array}{l}\text { WITHOUT } \\
\text { antibiotics } \\
n=1498(\%)\end{array}$ & Odds ratio $(95 \% \mathrm{Cl})$ & $p$ value \\
\hline Anemia $(\mathrm{Hb}<12 \mathrm{~g} / \mathrm{dL})$ & 12,646 & $3760(29.7)$ & $3432(30.1)$ & $328(26.2)$ & $1.21(1.06-1.39)$ & 0.004 \\
\hline Thrombocytosis (Platelet count $>180$ ) & 12,631 & $10,191(80.7)$ & $9211(80.9)$ & $980(78.5)$ & $1.16(1.01-1.34)$ & 0.036 \\
\hline Leukocytosis (Leukocytes > 10,000) & 12,644 & $2401(19.0)$ & 2255 (19.8) & $146(11.7)$ & $1.87(1.56-2.23)$ & $<0.001$ \\
\hline Leukopenia (Leukocytes < 4000) & & $11,150(88.2)$ & $10,073(88.4)$ & $1,077(86.2)$ & $1.22(1.03-1.45)$ & 0.020 \\
\hline Lymphopenia (Lymphocytes < 1300) & 12,626 & $4811(38.1)$ & $4211(37.0)$ & $600(48.2)$ & $0.63(0.56-0.71)$ & $<0.001$ \\
\hline \multicolumn{7}{|c|}{ Evolution of inflammatory parameters associated with covid-19 } \\
\hline C-reactive protein $>50 \mathrm{mg} / \mathrm{L}$ & 12,248 & $4049(33.1)$ & $3761(34.0)$ & $288(24.3)$ & $1.61(1.40-1.85)$ & $<0.001$ \\
\hline Procalcitonin $>0.5 \mathrm{ng} / \mathrm{mL}$ & 4907 & $606(12.4)$ & $575(13.1)$ & $31(6.3)$ & $2.25(1.55-3.27)$ & $<0.001$ \\
\hline Ferritin $>274 \mathrm{mcg} / \mathrm{L}$ & 6149 & $4967(80.8)$ & $4506(81.7)$ & $461(73.2)$ & $1.63(1.35-1.97)$ & $<0.001$ \\
\hline Fibrinogen $>650 \mathrm{mg} / \mathrm{dL}$ & 7852 & $2920(37.2)$ & $2602(37.1)$ & $318(38.3)$ & $0.95(0.82-1.10)$ & 0.50 \\
\hline$C K>200 \mathrm{U} / \mathrm{L}$ & 5775 & $697(12.1)$ & $657(12.4)$ & $40(8.6)$ & $1.50(1.08-2.10)$ & 0.017 \\
\hline $\mathrm{LDH}>300 \mathrm{U} / \mathrm{L}$ & 11,264 & $5002(44.4)$ & $4593(45.3)$ & $409(36.8)$ & $1.42(1.25-1.62)$ & $<0.001$ \\
\hline $\mathrm{IL}-6>4.3 \mathrm{pg} / \mathrm{mL}$ & 2074 & $1593(76.8)$ & $1428(76.9)$ & $165(75.7)$ & $1.07(0.77-1.49)$ & 0.68 \\
\hline D-Dimer $>250$ ng/mL & 9605 & $8367(87.1)$ & 7570 (87.8) & 797 (81.2) & $1.66(1.40-1.97)$ & $<0.001$ \\
\hline
\end{tabular}

Table 20 Laboratory outcomes after using macrolides

\begin{tabular}{|c|c|c|c|c|c|c|}
\hline 1 week after admission & Total $(n=13,932)$ & No. (\%) & $\begin{array}{l}\text { With } \\
\text { macrolides } \\
n=8382(\%)\end{array}$ & $\begin{array}{l}\text { Without } \\
\text { macrolides } \\
n=5502(\%)\end{array}$ & Odds ratio $(95 \% \mathrm{Cl})$ & $\begin{array}{l}\text { No. Total } \\
(n=13,932)\end{array}$ \\
\hline Anemia $(\mathrm{Hb}<12 \mathrm{~g} / \mathrm{dL})$ & 12,778 & $3800(29.7)$ & $2346(29.8)$ & $3439(29.7)$ & $1.00(0.93-1.08)$ & 0.97 \\
\hline Thrombocytosis (Platelet count $>180$ ) & 12,763 & $10,293(80.7)$ & $6504(82.6)$ & $3789(77.6)$ & $1.37(1.25-1.50)$ & $<0.001$ \\
\hline Leukocytosis (Leukocytes > 10,000) & 12,776 & $2439(19.1)$ & $1611(20.4)$ & $828(16.9)$ & $1.26(1.15-1.38)$ & $<0.001$ \\
\hline Leukopenia (Leukocytes < 4000) & & $11,262(88.2)$ & 7008 (88.9) & $4254(87.0)$ & $1.19(1.07-1.33)$ & 0.001 \\
\hline Lymphopenia (Lymphocytes < 1300) & 12,758 & $4844(38.0)$ & $3006(38.2)$ & $1838(37.6)$ & $1.02(0.95-1.10)$ & 0.55 \\
\hline \multicolumn{7}{|c|}{ Evolution of inflammatory parameters associated with COVID-19 } \\
\hline C-reactive protein $>50 \mathrm{mg} / \mathrm{L}$ & 12,375 & $4102(33.2)$ & $2418(31.6)$ & $1684(35.7)$ & $0.83(0.77-0.90)$ & $<0.001$ \\
\hline Procalcitonin $>0.5 \mathrm{ng} / \mathrm{mL}$ & 4970 & $621(12.5)$ & $368(12.6)$ & $253(12.3)$ & $1.03(0.86-1.22)$ & 0.77 \\
\hline Ferritin $>274 \mathrm{mcg} / \mathrm{L}$ & 6196 & $5010(80.9)$ & $3376(80.7)$ & $1634(81.2)$ & $0.97(0.84-1.11)$ & 0.62 \\
\hline Fibrinogen $>650 \mathrm{mg} / \mathrm{dL}$ & 7927 & $2953(37.3)$ & $1622(34.6)$ & $1331(41.0)$ & $0.76(0.69-0.83)$ & $<0.001$ \\
\hline$C K>200 \mathrm{U} / \mathrm{L}$ & 5828 & $706(12.1)$ & $426(11.6)$ & $280(12.9)$ & $0.89(0.76-1.04)$ & 0.15 \\
\hline $\mathrm{LDH}>300 \mathrm{U} / \mathrm{L}$ & 11,385 & $5065(44.5)$ & $3271(45.9)$ & $1794(42.2)$ & $1.16(1.08-1.25)$ & $<0.001$ \\
\hline $\mathrm{IL}-6>4.3 \mathrm{pg} / \mathrm{mL}$ & 2097 & $1613(76.9)$ & $1124(76.1)$ & $489(79)$ & $0.84(0.67-1.06)$ & 0.14 \\
\hline D-dimer $>250 \mathrm{ng} / \mathrm{mL}$ & 9698 & $8452(87.2)$ & 5462 (89.6) & $2990(83.0)$ & $1.77(1.57-1.99)$ & $<0.001$ \\
\hline
\end{tabular}

researchers, such as the Greek group Karampela et al., recommend fluoroquinolones when starting antibiotic therapy [19] based on the fact that these quinoline derivatives (the prodrome of chloroquine) appear to have an ability to suppress SARS-CoV-2 replication by exhibiting a stronger capacity for binding to its main protease than chloroquine and antiretrovirals such as nelfinavir [62, 63].

The Spanish group García-Vidal et al. aimed to determine the epidemiology, impact, and outcomes of coinfections in a cohort of 989 consecutive patients hospitalized with COVID-19 [64]. A total of 88 coinfections were documented in 72 patients (7.3\%). They recommend using empiric antibiotic therapy only in COVID-19 patients who had a chest $\mathrm{x}$-ray suggestive of associated bacterial pneumonia, those who required admission to the ICU, and those who were previously immunosuppressed.

We conclude that the use of antibiotic therapy has been unreasonable given that nearly $90 \%$ of patients admitted to internal medicine departments received them empirically $(12,238$ of 13,932 patients, $87.8 \%)$. The most 
Table 21 Decision to start antibiotic therapy based on initial inflammatory parameters

\begin{tabular}{|c|c|c|c|c|c|c|}
\hline On admission & Total $(n=13,932)$ & No. (\%) & $\begin{array}{l}\text { With antibiotics } \\
n=12,238(\%)\end{array}$ & $\begin{array}{l}\text { Without } \\
\text { antibiotics } \\
n=1498(\%)\end{array}$ & Odds ratio $(95 \% \mathrm{Cl})$ & $p$ value \\
\hline Anemia $(\mathrm{Hb}<12 \mathrm{~g} / \mathrm{dL})$ & 13,622 & $2337(17.2)$ & $2082(17.1)$ & $255(17.8)$ & $0.95(0.83-1.10)$ & 0.51 \\
\hline Thrombocytosis (Platelet count $>180$ ) & 13,636 & $7533(55.2)$ & $6718(55.1)$ & $815(56.5)$ & $0.95(0.85-1.06)$ & 0.32 \\
\hline Leukocytosis (Leukocytes > 10.000 & 13,620 & $2077(15.3)$ & $1884(15.5)$ & $193(13.5)$ & $1.18(1.01-1.38)$ & 0.046 \\
\hline Leukopenia (Leukocytes < 4000) & & $1871(13.7)$ & $1658(13.6)$ & $213(14.9)$ & $1.11(0.95-1.29)$ & 0.19 \\
\hline Lymphopenia (Lymphocytes < 1300) & 13,613 & $10,375(76.2)$ & $9401(77.2)$ & $974(67.6)$ & $0.61(0.55-0.69)$ & $<0.001$ \\
\hline C-reactive protein $>50 \mathrm{mg} / \mathrm{L}$ & 13,127 & $7130(54.3)$ & $6615(56.3)$ & $515(37.5)$ & $2.14(1.91-2.41)$ & $<0.001$ \\
\hline Procalcitonin $>0.5 \mathrm{ng} / \mathrm{mL}$ & 6452 & $764(11.8)$ & $716(12.3)$ & $48(7.5)$ & $1.73(1.28-2.35)$ & $<0.001$ \\
\hline Ferritin $>274 \mathrm{mcg} / \mathrm{L}$ & 5325 & $4084(76.7)$ & $3758(78.0)$ & $326(64.7)$ & $1.93(1.59-2.35)$ & $<0.001$ \\
\hline Fibrinogen $>650 \mathrm{mg} / \mathrm{dL}$ & 8789 & $3710(42.2)$ & $3336(42.4)$ & $374(40.6)$ & $1.08(0.94-1.24)$ & 0.28 \\
\hline CK $>200 \mathrm{U} / \mathrm{L}$ & 6844 & $1436(21.0)$ & $1331(21.3)$ & $105(18.0)$ & $1.23(0.98-1.53)$ & 0.07 \\
\hline $\mathrm{LDH}>300 \mathrm{U} / \mathrm{L}$ & 11,825 & $6568(55.5)$ & $5969(56.2)$ & 599 (49.6) & $1.30(1.16-1.47)$ & $<0.001$ \\
\hline IL-6 > $4.3 \mathrm{pg} / \mathrm{mL}$ & 1767 & $1550(87.7)$ & $1400(88.4)$ & $150(81.5)$ & $1.73(1.16-2.59)$ & 0.007 \\
\hline D-dimer $>250 \mathrm{ng} / \mathrm{mL}$ & 10,590 & $9226(87.1)$ & $8310(87.4)$ & $916(84.7)$ & $1.26(1.05-1.50)$ & 0.011 \\
\hline
\end{tabular}

Table 22 Decision to start antibiotic therapy (and which one) based on initial inflammatory parameters

\begin{tabular}{|c|c|c|c|c|c|c|}
\hline \multirow[t]{2}{*}{ On admission } & \multicolumn{2}{|c|}{ Beta-lactams } & \multicolumn{2}{|c|}{ Macrolides } & \multicolumn{2}{|c|}{ Quinolones } \\
\hline & No (Total) & N. (\%) & No (Total) & N. (\%) & No (Total) & N. (\%) \\
\hline Anemia $(\mathrm{Hb}<12 \mathrm{~g} / \mathrm{dL})$ & 2368 & $1737(73.4)$ & 2364 & $1339(56.6)$ & 2346 & $330(14.1)$ \\
\hline Thrombocytosis (Platelet count $>180$ ) & 7627 & $5462(71.6)$ & 7619 & $4709(61.8)$ & 7556 & $977(12.9)$ \\
\hline Leukocytosis (Leukocytes > 10,000 & 2098 & $1602(76.4)$ & 2094 & $1222(58.4)$ & 2084 & $317(15.2)$ \\
\hline Leukopenia (Leukocytes < 4000) & 1903 & $1333(70.1)$ & 1901 & $1114(58.6)$ & 1884 & $275(14.6)$ \\
\hline Lymphopenia (Lymphocytes < 1300) & 10,500 & $7832(74.6)$ & 10,492 & $6432(61.30)$ & 10,412 & $1445(13.9)$ \\
\hline C-reactive protein $>50 \mathrm{mg} / \mathrm{L}$ & 7214 & $5653(78.4)$ & 7212 & $4557(63.2)$ & 7154 & $1012(14.2)$ \\
\hline Procalcitonin $>0.5 \mathrm{ng} / \mathrm{mL}$ & 776 & $651(83.9)$ & 774 & $445(57.5)$ & 768 & $110(14.3)$ \\
\hline Ferritin $>274$ mcg $/ \mathrm{L}$ & 4118 & $3021(73.4)$ & 4117 & $2869(69.7)$ & 4099 & $390(9.5)$ \\
\hline Fibrinogen $>650 \mathrm{mg} / \mathrm{dL}$ & 3749 & $2856(76.2)$ & 3751 & $2162(57.6)$ & 3720 & $432(11.6)$ \\
\hline$C K>200 \mathrm{U} / \mathrm{L}$ & 1459 & $1151(78.9)$ & 1454 & $927(63.8)$ & 1444 & $199(13.8)$ \\
\hline $\mathrm{LDH}>300 \mathrm{U} / \mathrm{L}$ & 6647 & $5052(76.0)$ & 6641 & $4381(66.0)$ & 6588 & $824(12.5)$ \\
\hline $\mathrm{IL}-6>4.3 \mathrm{pg} / \mathrm{mL}$ & 1563 & $1160(74.2)$ & 1564 & $1111(71.0)$ & 1556 & $110(7.1)$ \\
\hline D-dimer $>250 \mathrm{ng} / \mathrm{mL}$ & 9313 & $6652(71.4)$ & 9318 & $6032(64.7)$ & 9247 & $1158(12.5)$ \\
\hline
\end{tabular}

used antibiotics were beta-lactams (72.0\%), macrolides (60.2\%), and fluoroquinolones (13.3\%), which is in line with the available data from the rest of EU (European Union). This pattern of use can plausibly be attributed to the fact that empiric use of third-generation cephalosporins together with azithromycin was included in most hospital protocols in the first months of the pandemic.

The vast majority of our patients had community acquisition of COVID-19; only $6.6 \%$ acquired the infection in a hospital. Also of note is the fact that infection in nursing homes occurred in $<10 \%$ of cases. Antibiotic use, and specifically macrolide use, correlated to where the infection was contracted: their use was more common among those with community-acquired infection and less common among those who contracted the disease in nursing homes or the hospital.

\section{For which patient profiles should antibiotic therapy be considered?}

There appears to be broad consensus on initiating antibiotic treatment in all severely ill patients who require direct admission to the ICU upon arrival at the hospital $[24,59]$. However, most authors coincide in highlighting the difficulty of distinguishing SARS-CoV-2-related pneumonia versus atypical pneumonia or nosocomial ventilator-associated pneumonia in COVID-19 patients 
Table 23 Radiological outcomes after using antibiotics

\begin{tabular}{|c|c|c|c|c|c|c|}
\hline & Total $(n=13,932)$ & No. (\%) & $\begin{array}{l}\text { With antibiotics } \\
n=12,238(\%)\end{array}$ & $\begin{array}{l}\text { Without } \\
\text { antibiotics } \\
n=1498(\%)\end{array}$ & Odds ratio $(95 \% \mathrm{Cl})$ & $p$ value \\
\hline \multicolumn{7}{|l|}{ At admission } \\
\hline \multicolumn{7}{|l|}{ Condensation } \\
\hline No & 13,564 & $6962(51.3)$ & $6032(49.7)$ & $930(65.2)$ & 1. (ref) & - \\
\hline Unilateral & & $2383(17.6)$ & $2206(18.2)$ & $177(12.4)$ & $1.92(1.62-2.27)$ & $<0.001$ \\
\hline Bilateral & & $4219(31.1)$ & $3899(32.1)$ & $320(22.4)$ & $1.88(1.64-2.15)$ & $<0.001$ \\
\hline \multicolumn{7}{|l|}{ Interstitial infiltrates } \\
\hline No & 13,572 & $5074(37.4)$ & $4388(36.1)$ & $686(48.2)$ & 1. (ref) & - \\
\hline Unilateral & & $1399(10.3)$ & $1258(10.4)$ & $141(9.9)$ & $1.39(1.15-1.69)$ & 0.001 \\
\hline Bilateral & & 7099 (52.3) & $6503(53.5)$ & $596(41.9)$ & $1.71(1.52-1.92)$ & $<0.001$ \\
\hline \multicolumn{7}{|l|}{ Pleural effusion } \\
\hline No & 13,565 & $12,942(95.4)$ & $11,573(95.3)$ & $1369(96.1)$ & 1. (ref) & - \\
\hline Unilateral & & $411(3.0)$ & $377(3.1)$ & $34(2.4)$ & $1.31(0.92-1.87)$ & 0.14 \\
\hline Bilateral & & $212(1.6)$ & $191(1.6)$ & $21(1.5)$ & $1.08(0.68-1.69)$ & 0.75 \\
\hline Thoracic CT scan was performed & 13,618 & $774(5.7)$ & $721(5.9)$ & $53(3.6)$ & $1.68(1.26-2.23)$ & $<0.001$ \\
\hline $\begin{array}{l}\text { COVID-19 compatible findings on } \\
\text { Thoracic CT }\end{array}$ & 769 & $682(88.7)$ & $644(89.9)$ & $38(71.7)$ & $3.53(1.85-6.73)$ & $<0.001$ \\
\hline \multicolumn{7}{|l|}{ One week after admission } \\
\hline \multicolumn{7}{|l|}{ Condensation } \\
\hline No & 10,132 & $4709(46.5)$ & $4123(45.0)$ & $586(60.9)$ & 1. (ref) & - \\
\hline Unilateral & & $1406(13.9)$ & $1291(14.1)$ & $115(12.0)$ & $1.60(1.29-1.97)$ & $<0.001$ \\
\hline Bilateral & & $4017(39.7)$ & $3756(41.0)$ & $261(27.1)$ & $2.04(1.76-2.38)$ & $<0.001$ \\
\hline \multicolumn{7}{|l|}{ Interstitial infiltrates } \\
\hline No & 10,119 & $3562(35.2)$ & $3101(33.9)$ & $461(48.1)$ & 1. (ref) & - \\
\hline Unilateral & & $753(7.4)$ & $685(7.5)$ & $68(7.1)$ & $1.50(1.15-1.96)$ & 0.003 \\
\hline Bilateral & & $5804(57.4)$ & $5374(58.7)$ & $430(44.8)$ & $1.86(1.62-2.13)$ & $<0.001$ \\
\hline \multicolumn{7}{|l|}{ Pleural effusion } \\
\hline No & 10,111 & $9647(95.4)$ & 8719 (95.3) & $928(96.9)$ & 1. (ref) & - \\
\hline Unilateral & & $302(3.0)$ & $282(3.1)$ & $20(2.1)$ & $1.50(0.95-2.37)$ & 0.08 \\
\hline Bilateral & & $162(1.6)$ & $152(1.7)$ & $10(1.1)$ & $1.62(0.85-3.08)$ & 0.14 \\
\hline Radiological worsening & 10,154 & $4034(39.7)$ & $3774(41.1)$ & $260(26.9)$ & $1.89(1.63-2.20)$ & $<0.001$ \\
\hline
\end{tabular}

Table 24 Radiological evolution among those who used antibiotic therapy

\begin{tabular}{|c|c|c|c|c|c|c|}
\hline \multirow{2}{*}{ On admission } & No. $($ Total $=12238)$ & No. (\%) & & No $($ Total $=12238)$ & No. (\%) & $p$ value \\
\hline & \multicolumn{6}{|c|}{ One week after admission } \\
\hline Condensation & 12,137 & $6105(50.3)$ & Condensation & 9170 & $5047(55.0)$ & $<0.001$ \\
\hline Interstitial infiltrates & 12,149 & 7761 (63.9) & Interstitial infiltrates & 9160 & $6059(66.2)$ & 0.001 \\
\hline Pleural effusion & 12,141 & $568(4.7)$ & Pleural effusion & 9153 & $434(4.7)$ & 0.15 \\
\hline
\end{tabular}

Table 25 Radiological evolution among those who used macrolides

\begin{tabular}{|c|c|c|c|c|c|c|}
\hline \multirow{2}{*}{ On admission } & No. $($ Total $=8382)$ & No. (\%) & & No. $($ Total $=8382)$ & No. (\%) & $p$ value \\
\hline & \multicolumn{6}{|c|}{ One week after admission } \\
\hline Condensation & 8315 & $4301(51.7)$ & Condensation & 6390 & 3555 (55.6) & $<0.001$ \\
\hline Interstitial infiltrates & 8328 & $5440(65.3)$ & Interstitial infiltrates & 6386 & $4282(67.1)$ & 0.11 \\
\hline Pleural effusion & 8318 & $360(4.3)$ & Pleural effusion & 6382 & $278(4.4)$ & 0.58 \\
\hline
\end{tabular}


Table 26 Immunomodulatory therapies used among those who used antibiotic therapy

\begin{tabular}{|c|c|c|c|c|c|}
\hline & Total $(n=13,932)$ & No. (\%) & $\begin{array}{l}\text { With antibiotics } \\
n=12,238(\%)\end{array}$ & $\begin{array}{l}\text { Without antibiotics } \\
n=1498(\%)\end{array}$ & $p$ value \\
\hline Use of lopinavir/ritonavir & 13,719 & $8414(61.3)$ & $7590(62.1)$ & $824(55.0)$ & $<0.001$ \\
\hline Use of hydroxychloroquine & 13,727 & $11,727(85.4)$ & $10,677(87.3)$ & $1050(70.1)$ & $<0.001$ \\
\hline Use of beta-Interferon & 13,662 & 1585 (11.6) & $1488(12.2)$ & $97(6.5)$ & $<0.001$ \\
\hline Use of tocilizumab & 13,703 & $1145(8.4)$ & $1106(9.1)$ & $39(2.6)$ & $<0.001$ \\
\hline Use of anakinra & 13,604 & $76(0.6)$ & $76(0.6)$ & $0(0)$ & $<0.001$ \\
\hline Use of systemic corticosteroids & 13,689 & $4738(34.6)$ & $4500(36.9)$ & $238(16.0)$ & $<0.001$ \\
\hline Use of immunoglobulin & 13,483 & $62(0.5)$ & $60(0.5)$ & $2(0.1)$ & 0.06 \\
\hline
\end{tabular}

Table 27 Complications and clinical progress according to the use of antibiotic therapy

\begin{tabular}{|c|c|c|c|c|c|c|}
\hline & Total $(n=13,932)$ & No. (\%) & $\begin{array}{l}\text { With } \\
\text { antibiotics } \\
n=12,238(\%)\end{array}$ & $\begin{array}{l}\text { Without } \\
\text { antibiotics } \\
n=1498(\%)\end{array}$ & Odds ratio $(95 \% \mathrm{Cl})$ & $p$ value \\
\hline Bacterial pneumonia & 13,673 & $1481(10.8)$ & $1441(11.8)$ & $40(2.7)$ & $4.85(3.52-6.67)$ & $<0.001$ \\
\hline \multicolumn{7}{|l|}{ ARDS } \\
\hline No & 13,650 & $9190(67.3)$ & $7955(65.4)$ & $1235(83.3)$ & 1 (ref.) & - \\
\hline Mild & & $1093(8.0)$ & $1033(8.5)$ & $60(4.1)$ & $2.67(2.05-3.49)$ & $<0.001$ \\
\hline Moderate & & $967(7.1)$ & $927(7.6)$ & $40(2.7)$ & $3.60(2.61-4.97)$ & $<0.001$ \\
\hline Severe & & $2400(17.6)$ & $2252(18.5)$ & $149(10.0)$ & $2.36(1.98-2.82)$ & $<0.001$ \\
\hline Acute heart failure & 13,677 & $782(5.7)$ & $716(5.9)$ & $66(4.4)$ & $1.34(1.04-1.74)$ & 0.025 \\
\hline Arrhythmia & 13,669 & $532(3.9)$ & $508(4.2)$ & $24(1.6)$ & $2.65(1.75-4.01)$ & $<0.001$ \\
\hline Epileptic seizures & 13,680 & $81(0.6)$ & $74(0.6)$ & $7(0.5)$ & $1.29(0.59-2.81)$ & 0.52 \\
\hline Stroke & 13,672 & $91(0.7)$ & $82(0.7)$ & $9(0.6)$ & $1.11(0.56-2.22)$ & 0.76 \\
\hline Acute kidney failure & 13,673 & $1897(13.9)$ & $1757(14.4)$ & $140(9.4)$ & $1.62(1.35-1.94)$ & $<0.001$ \\
\hline Sepsis & 13,667 & $822(6.0)$ & $780(6.4)$ & $42(2.8)$ & $2.35(1.72-3.23)$ & $<0.001$ \\
\hline Shock & 13,656 & $605(4.4)$ & $582(4.8)$ & $23(1.6)$ & $3.19(2.10-4.86)$ & $<0.001$ \\
\hline Disseminated intravascular coagulation (DIC) & 13,655 & $155(1.1)$ & $145(1.2)$ & $10(0.7)$ & $1.78(0.94-3.39)$ & 0.08 \\
\hline High-flow nasal cannula & 13,635 & $1089(8.0)$ & $1027(8.5)$ & $62(4.2)$ & $2.11(1.63-2.75)$ & $<0.001$ \\
\hline Non-invasive mechanical ventilation & 13,692 & $668(4.9)$ & $642(5.3)$ & $26(1.7)$ & $3.13(2.11-4.66)$ & $<0.001$ \\
\hline Invasive mechanical ventilation & 13,696 & $874(6.4)$ & $848(7.0)$ & $26(1.7)$ & $4.21(2.84-6.25)$ & $<0.001$ \\
\hline Prone positioning & 13,676 & $1361(10.0)$ & $1316(10.8)$ & $45(3.0)$ & $3.89(2.87-5.26)$ & $<0.001$ \\
\hline Intensive care unit admission & 13,727 & $1095(8.0)$ & $1057(8.6)$ & $38(2.5)$ & $3.63(2.62-5.04)$ & $<0.001$ \\
\hline Death during hospitalization & 13,736 & $2840(20.7)$ & $2597(21.2)$ & $243(16.2)$ & $1.39(1.20-1.61)$ & $<0.001$ \\
\hline $\begin{array}{l}\text { Death during hospitalization and during } \\
\text { readmission }\end{array}$ & 13,549 & 2906 (21.5) & $2653(22.0)$ & $253(17.0)$ & $1.37(1.19-1.58)$ & $<0.001$ \\
\hline
\end{tabular}

based on symptoms alone, given that all present with similar signs and symptoms consisting of fever, dry cough, dyspnea, and bilateral involvement on imaging tests. For this reason, they argue that physicians should avail themselves of analytical results when making a decision on whether or not to use antibiotics $[10,26,32,39$, 65].

Indeed, this is precisely what is being done on a daily basis at the patient's bedside. In research by Beovic et al., physicians indicated that patients' clinical presentation was the most significant factor when considering starting antibiotic therapy, followed by elevated inflammatory parameters on laboratory tests and radiological findings of pneumonia. Among the analytical results, the most relevant were elevated procalcitonin levels, the neutrophil count, the degree of leukocytosis, and elevated C-reactive protein (CRP) levels [37].

In our population, we found that the most critical clinical information used when determining whether to begin empiric antibiotic therapy in COVID-19 patients was symptoms such as the presence of fever, dyspnea, and cough (especially productive) were similar to what was reported in the literature. Other symptoms that are more closely related to viral infections, such as arthralgia; 
Table 28 Resolution of covid-19 according to use of antibiotic therapy

\begin{tabular}{|c|c|c|c|c|c|c|}
\hline & Total $(n=13,932)$ & No. (\%) & $\begin{array}{l}\text { With antibiotics } \\
n=12,238(\%)\end{array}$ & $\begin{array}{l}\text { Without } \\
\text { antibiotics } \\
n=1498(\%)\end{array}$ & Odds ratio $(95 \% \mathrm{Cl})$ & $p$ value \\
\hline Hospital stay in days, median (IQR) & 13,736 & $8(5-13)$ & $9(5-14)$ & $7(4-11)$ & $0.99(0.99-1)$ & 0.16 \\
\hline \multicolumn{7}{|l|}{ Clinical outcomes } \\
\hline Improvement: Discharge home & 13,736 & $10,107(73.6)$ & $8938(73.0)$ & $1169(78.0)$ & 1 (ref.) & - \\
\hline Discharge to other care centers & & $789(5.7)$ & $703(5.7)$ & $86(5.7)$ & $1.07(0.85-1.35)$ & 0.57 \\
\hline Death during hospitalization & & $2840(20.7)$ & $2597(21.2)$ & $243(16.2)$ & $1.40(1.21-1.62)$ & $<0.001$ \\
\hline \multicolumn{7}{|l|}{ Cause of death } \\
\hline COVID-19 & 2796 & $2629(94.0)$ & $218(91.6)$ & $2411(94.3)$ & 1 (ref.) & - \\
\hline Other causes & & $167(6.0)$ & $147(5.8)$ & $20(8.4)$ & $0.66(0.41-1.08)$ & 0.10 \\
\hline Hospital readmission & 13,308 & $506(3.8)$ & $444(3.8)$ & $62(4.2)$ & $0.88(0.67-1.16)$ & 0.37 \\
\hline Days until readmission, median (IQR) & 505 & $9(3-17)$ & $7(3-16)$ & $9(3-18)$ & $1.00(0.98-1.02)$ & 0.89 \\
\hline \multicolumn{7}{|l|}{ Cause of readmission } \\
\hline COVID-19 & 504 & $208(41.3)$ & $176(39.8)$ & $32(51.6)$ & 1 (ref.) & - \\
\hline Other causes & & $296(58.7)$ & $266(60.2)$ & $30(48.4)$ & $1.61(0.95-2.75)$ & 0.08 \\
\hline $\begin{array}{l}\text { Death during hospitalization and dur- } \\
\text { ing readmission }\end{array}$ & 13,549 & $2906(21.5)$ & $2653(22.0)$ & $253(17.0)$ & $1.37(1.19-1.58)$ & $<0.001$ \\
\hline
\end{tabular}

Table 29 Use of antibiotic therapy and relationship to mortality (Multivariate analysis adjusted according to clinical variables)

\begin{tabular}{lll}
\hline & Odds ratio (95\% Cl) & $\boldsymbol{p}$ value \\
\hline Use of antibiotic therapy & $1.20(0.94-1.53)$ & 0.14 \\
Age & $1.08(1.07-1.09)$ & $<0.001$ \\
Smoking status & & \\
$\quad$ Never & $1.38(1.19-1.59)$ & $<$ (ref.) \\
Former & $1.63(1.21-2.20)$ & 0.001 \\
Current & & \\
Fever & - & $1($ ref.) \\
No $\left(<37^{\circ} \mathrm{C}\right)$ & $0.98(0.80-1.20)$ & 0.84 \\
Low-grade fever $\left(37-37.9^{\circ} \mathrm{C}\right)$ & $0.86(0.72-1.03)$ & 0.10 \\
Fever $\left(>38^{\circ} \mathrm{C}\right)$ & $1.30(1.13-1.49)$ & $<0.001$ \\
Shortness of breath & $2.21(1.92-2.55)$ & $<0.001$ \\
Oxygen saturation $<90 \%$ & $1.93(1.68-2.21)$ & $<0.001$ \\
Tachypnea & $1.01(1.01-1.02)$ & $<0.001$ \\
C-reactive protein $(\mathrm{mg} / \mathrm{L})$ & $4.78(3.81-5.99)$ & $<0.001$ \\
Procalcitonin $(\mathrm{ng} / \mathrm{mL})>0.15$ & $1.50(1.30-1.71)$ & $<0.001$ \\
Use of systemic corticosteroids & $1.90(1.50-2.40)$ & $<0.001$ \\
Use of tocilizumab & &
\end{tabular}

fatigue; anorexia; and gastrointestinal symptoms such as nausea, vomiting, and diarrhea, are also associated with greater use of antibiotics. On the other hand, the presence of anosmia, ageusia, headache, or abdominal pain did not seem to have an influence on antibiotic use. The most relevant data on the physical examination were those that reflected more severe disease: oxygen saturation $<90 \%$, tachypnea, and tachycardia. Furthermore,
Table 30 Use of macrolides and relationship to mortality (Multivariate analysis adjusted according to clinical variables)

\begin{tabular}{lll}
\hline & Odds ratio (95\% Cl) & $\boldsymbol{p}$ value \\
\hline Use of macrolides & $0.64(0.56-0.73)$ & $<0.001$ \\
Age & $1.08(1.07-1.09)$ & $<0.001$ \\
Smoking status & & \\
$\quad$ Never & $1.38(1.19-1.59)$ & 1 (ref.) \\
Former & $1.62(1.21-2.18)$ & 0.001 \\
$\quad$ Current & & \\
Fever & - & 1 (ref.) \\
No $\left(<37^{\circ} \mathrm{C}\right)$ & $0.97(0.79-1.18)$ & 0.76 \\
Low-grade fever $\left(37-37.9^{\circ} \mathrm{C}\right)$ & $0.87(0.73-1.04)$ & 0.12 \\
Fever $\left(>38^{\circ} \mathrm{C}\right)$ & $1.31(1.14-1.51)$ & $<0.001$ \\
Shortness of breath & $0.45(0.39-0.51)$ & $<0.001$ \\
Oxygen saturation $>90 \%$ & $1.95(1.70-2.24)$ & $<0.001$ \\
Tachypnea & $1.01(1.00-1.01)$ & $<0.001$ \\
C-reactive protein $(\mathrm{mg} / \mathrm{L})$ & $4.83(3.86-6.04)$ & $<0.001$ \\
Procalcitonin $(\mathrm{ng} / \mathrm{mL})>0.15$ & $1.60(1.39-1.84)$ & $<0.001$ \\
Use of systemic corticosteroids & $1.89(1.49-2.39)$ & $<0.001$ \\
\hline Use of tocilizumab & & \\
\hline
\end{tabular}

patients who had crackles and rhonchi were more likely to receive antibiotics, findings that were statistically significant; those with wheezing were also more likely to receive antibiotics, but this finding was not significant.

In regard to patients' previous treatment, it would be logical to believe that those on immunosuppressive treatments would have received antibiotics at a higher rate, but no differences were observed in antibiotic use 
according to prior immunosuppressive treatment and as such, these drugs were not found to be critical in decision-making regarding use of antibiotics. Only those taking hydroxychloroquine were observed to have received antibiotics more often. Among the group that received macrolides, antibiotics were used less frequently among those being treated with systemic corticosteroids or biological therapies.

Concerning the influence of analytical parameters on the decision to start antibiotic therapy, the results are clear: the elevation of inflammatory parameters such as CRP, procalcitonin, ferritin, LDH (lactate deshidrogenase), and D-dimer have proven to be the most relevant factors in the decision to begin antibiotic treatment, as indicated in previous works. Leukocytosis, interpreted as a sign of risk of bacterial infection, was related to greater use of antibiotics whereas lymphopenia, more often linked with viral symptoms, was inversely related to the use of antibiotics.

Rapid characterization of co-infection is essential in order to properly guide antibiotic management and could help to save lives during the pandemic [57]. Huttner et al. recommended that in cases in which antibiotics are to be started, microbiological samples such as a urinary antigen test for Legionella and blood cultures, should be obtained beforehand in order to diagnose the coinfection [26]. Mirzaei et al. also advocated for a proper diagnosis, noting the importance of a broad-spectrum molecular diagnostic panel for rapid detection of the most common respiratory pathogens [39].

We believe that actively searching for possible bacterial co-infection and early diagnosis are aspects of caring for COVID-19 patients that must be improved. A urinary antigen test for Legionella and S. pneumoniae was performed in less than half of patients and though there was a very small rate of positive tests (1.5\%), mortality was found to be higher among those who did test positive. Antibiotic therapy was used less frequently in patients who did not have a urinary antigen test, but this is likely due to little suspicion of initial bacterial co-infection that resulted in these patients not being prescribed antibiotics. Unfortunately, we do not have information on blood or sputum cultures; this is a possible area of future research.

\section{Comparisons to other studies}

Other retrospective case series similar to ours found. A work by Argenziano et al. analyzed the first 1000 patients hospitalized for COVID-19 in the New York City region [34]. The mean age was 63.0 years and predominantly male $(57.5 \%)$. There were high rates of baseline comorbidities, the most common of which were hypertension and diabetes mellitus. The most common symptoms on admission were dry cough (73.2\%), fever (72.8\%), and dyspnea (63.1\%). They also report that patients with marked elevation of inflammatory parameters (CRP, ESR -erythrocyte sedimentation rate-, D-dimer, ferritin, and $\mathrm{LDH}$ ) were those who most frequently required transfer to the ICU. In this series, $21.1 \%$ of patients across all levels of care died ( $14 \%$ when only considering patients in conventional wards).

Suleyman et al., in a series of 463 cases in Detroit, studied a population with a mean age of 57.5 years that was predominantly female (55.9\%) and African American (72.1\%) [35]. Virtually all patients (94\%) had at least one comorbidity, the most common of which were hypertension (63.7\%), chronic kidney disease (39.3\%), and diabetes (38.4\%). They had similar symptoms upon admission as those in our study: cough (74.9\%), fever (68.0\%) and dyspnea (60.9\%). A higher death rate (20\%) was observed in this work compared to previous studies, with male gender and age (over 60 years) shown to be the most relevant risk factors.

In Liang et al's work on a cohort of 1590 cases in China, a younger mean age was observed: 48.9 years. Nine hundred and four (57.3\%) patients were male and $399(25.1 \%)$ had comorbidities, including hypertension (16.9\%), diabetes $(8.2 \%)$, and cardiovascular disease (3.7\%). Fever $(88.0 \%)$, dry cough $(70.2 \%)$, fatigue $(42.8 \%)$, productive cough $(36.0 \%)$ and shortness of breath $(20.8 \%)$ were the most common symptoms [66]. The overall rates of severe cases and fatality was $16.0 \%$ and $3.2 \%$, respectively.

Our cohort of patients had a mean age of 69.0 years, which is older than in the mentioned studies; the mean age was even higher among the group which received antibiotics. One finding that merits mention is that the use of antibiotic therapy was lower in the group of patients over 80 years of age and in frail patients, defined as those with dementia, neurodegenerative diseases, or a high degree of dependence. In regard to the rest of the demographic data and comorbidities, no differences were noted in terms of use of antibiotic therapy except for among men and those with cardiovascular risk factors (hypertension, dyslipidemia, and diabetes), in which there was a higher percentage of use.

We found higher death rates in our patient sample compared to previous research. The overall fatality rate was $20.7 \%$ ( 2840 of 13,736 patients). A striking finding was the higher death rate among those who received any antibiotic (OR 1.39, 95\% CI 1.20-1.61) except macrolides, in which there was a higher survival rate (OR $0.70,95 \%$ CI $0.64-$ $0.76 ; p<0.001)$. Even considering that use of antibiotic therapy was lower in patients who a priori had a higher risk of dying, namely older or more frail patients, the relationship between antibiotic therapy and fatality persisted 
even after controlling for these confounding favors on the logistic regression (OR 1.52, 95\% CI 1.29-1.80).

In terms of the clinical progress of patients in whom antibiotics were used, improvement was observed in most inflammatory parameters, though there was radiological worsening, with an increase in the proportion of patients with consolidation or interstitial infiltrates. Moreover, antibiotics did not diminish the risk of developing bacterial co-infections among hospitalized patients, as bacterial pneumonia was found in 1481 patients $(10.8 \%)$ and it was more frequent in those who received antibiotics.

Other complications occurred more frequently during hospitalization, including acute respiratory distress syndrome, acute cardiac failure, arrhythmias, acute renal failure, shock or sepsis, and increased demand for respiratory support (oxygen via high-flow nasal cannula, non-invasive mechanical ventilation, invasive mechanical ventilation, and prone positioning). A higher percentage of patients in the group that received antibiotics required ICU admission. These findings could possibly be explained by the fact that use of empiric antibiotic therapy was widely generalized; its use was only limited among patients who were very frail (and thus not candidates for invasive measures) or, on the contrary, among patients with very mild symptoms.

\section{The role of macrolides}

Macrolides have been proposed as a possible treatment for severe acute respiratory distress syndrome caused by COVID-19 since the first months of the pandemic [21, 23]. These bactericidal antibiotics are widely used in habitual clinical practice against gram positive and atypical bacteria species that are usually associated with respiratory tract infections. The antiviral effects of macrolides have attracted considerable attention. Their ability to modulate the immune response and decrease the production of inflammatory cytokines makes them a very interesting tool for battling respiratory viral infections. The efficacy of macrolides in the treatment of other respiratory viruses such as rhinovirus, respiratory syncytial virus, and influenza has long been established [22, 25]. In addition to the aforementioned respiratory viruses, azithromycin has also been reported to inhibit Zika virus [24].

In terms of COVID-19, azithromycin was one of the drugs included in the large adaptive RECOVERY trial [67]. Based on preclinical and clinical evidence and some preliminary results in COVID-19 patients, azithromycin could have potential in the fight against this new disease [68].

In a clinical trial led by Gautret et al. in France, a combination of hydroxychloroquine and azithromycin was shown to be effective against COVID-19 [69]. Treatment efficacy was compared in 36 patients divided into three groups: six patients were treated with hydroxychloroquine combined with azithromycin, 14 with hydroxychloroquine in monotherapy, and 16 with a placebo. The results showed that by the sixth day of treatment, all patients in the HCQ + AZM group had no detectable virus in nasopharyngeal exudate samples compared to $57.1 \%$ of the HCQ group and $12.5 \%$ of the control group $(p<0.001)$.

In our study, we found a favorable outcome with the use of macrolides compared to other antibiotics. As we have highlighted, the mortality rate was lower in the macrolides group (unlike with other antibiotics) and indeed, the survival ratio was higher among patients who received them, a finding that was statistically significant (OR 0.70, 95\% CI 0.64-0.76). Patients in whom macrolides were used were younger than those who received other antibiotics (68 years vs. 71 years). In order to control for possible confounding variables, a multivariate analysis was conducted that showed that the use of macrolides in our population continued to be linked to a lower mortality rate (OR $0.80,95 \%$ CI $0.73-0.88$ ).

Huttner et al. consider that macrolides and quinolones should be avoided due to the risk of cardiotoxicity [37]. Along these lines, a lower rate of use of azithromycin was observed among patients with previous heart disease in our study.

The risk of a rise in multidrug-resistant germs due to indiscriminate antibiotic use has been described in the literature [70-72]. The exact incidence of bacterial superinfections in COVID-19 patients is still not entirely clear and the incidence seems to be much lower than in severe influenza [8]. We agree with many other authors that establishing clear criteria for initiating antibiotic therapy in COVID-19 patients is essential in order to prevent the consequences of inappropriate prescribing $[26,37,64]$. We must be aware that a potential consequence of the COVID-19 pandemic is the long-term propagation of antimicrobial resistance resulting from increased patient exposure to antimicrobials that are often suboptimally or inappropriately used [72, 73]. This rapid growth in antibiotic prescribing can exercise a strong selective pressure on bacterial pathogens to develop resistance, leading to increased incidence of drug-resistant bacterial infections in the years following the COVID-19 pandemic. It has been calculated that ten million people could die from antibiotic-resistant bacterial infections each year by 2050 [39].

Recently, a group of members of ESCMID's Study Group for Antimicrobial Stewardship (ESGAP) published a paper warning against non-critical use of antibiotics in 
COVID-19 patients along with some practical recommendations. Huttner et al. indicate that we should periodically reevaluate the suitability of our prescription and discontinue it as soon as possible when there is low suspicion of bacterial infection. In the event its continued use is warranted, switch to oral therapy early and give short cycles of five days [26]. It is important to educate healthcare providers in antimicrobial stewardship to prevent the consequences of excessive antimicrobial use such as toxicities, selection for opportunistic pathogens such as Clostridioides difficile (coinfection with SARS-CoV-2 results in a worsening of outcomes) and antimicrobial resistance $[74,75]$.

\section{Conclusion}

In this multicenter, retrospective study, the overall percentage of bacterial co-infection among patients with COVID-19 was low, but the use of antibiotics was high. There is insufficient evidence to support widespread use of empiric antibiotics in patients hospitalized for COVID-19. The majority of these patients may not require empiric antibacterial treatment and, if it is needed, there is promising evidence regarding the use of azithromycin as a potential treatment for COVID-19. However, more structured studies must be carried out in this regard.

Our outcomes provide evidence against the use of antibiotic therapy in most patients hospitalized for COVID19 since it has not been proven to reduce the mortality rate of these patients. We recommend against routinely prescribing antibiotics to all hospitalized patients with COVID-19.

\section{Future lines of research}

There is a lack of data on bacterial co-infections in COVID-19 patients. This information is essential for determining the role of empiric antimicrobial therapy and antibiotic stewardship strategies. Biomarkers (CRP, procalcitonin) may play a role in deciding which patients should not receive antibiotics, but further investigation is required.

Prospective clinical studies on antibiotic prescription and systematic analyses of COVID-19 patients diagnosed with bacterial co-infection must conducted in order to evaluate the influence of current and future viral pandemics on antimicrobial resistance and the development of superinfections. This line of research is critical for avoiding unintended consequences resulting in broad antimicrobial resistance in the near future.

Lastly, standard guidelines for the administration of the antibiotics must be established.

\section{Abbreviations}

SARS-CoV-2: Severe acute respiratory syndrome coronavirus 2; COVID-19: Coronavirus disease 2019; WHO: World Health Organization; FDA: Food and drugs administration; SEMI: Spanish society of internal medicine; Rt-PCR: Real time transcription polimerase chain reaction; IQR: Interquartile range; ANOVA: Analysis of variance; OR: Odds ratio; Cl: Confidence interval; ICU: Intensive care units; CT: Computerized tomography; SARS: Severe acute respiratory syndrome; MERS: Middle-East respiratory syndrome; EU: European Union; CRP: C-reactive protein; ESR: Erythrocyte sedimentation rate; LDH: Lactate deshidrogenase; CK: Creatinine kinase; ESCMID: European Society for Clinical Microbiology and Infectious Diseases; ESGAP: Study Group for Antimicrobial Stewardship; AIDS: Acquired immunodeficiency syndrome; HAART: Highly antiretroviral therapy.

\section{Supplementary Information}

The online version contains supplementary material available at https://doi. org/10.1186/s12879-021-06821-1.

Additional file 1. List of the SEMI-COVID-19 Network members.

\section{Acknowledgements}

We gratefully acknowledge all the investigators who participate in the SEMICOVID-19 Registry. We also thank to Claire Alexandra Conrad for her help with the final English-language version and the SEMI-COVID-19 Registry Coordinating Center, S\&H Medical Science Service, for their quality control data, logistic and administrative support.

\section{Authors' contributions}

ADBE and EFC contributed to the conception, design of the work the acquisition, statistical analyses, interpretation of data and drafted the initial manuscript. JMCR and JMN-C commented on the manuscript. All authors read and approved the final version.

Funding

There was no funding granted for this article.

\section{Availability of data and materials}

All data generated or analysed during this study are included in this published article and its Additional files.

\section{Declarations}

Ethics approval and consent to participate

This study was also carried out in accordance with the Declaration of Helsinki and was approved by the Institutional Research Ethics Committee of Málaga on March 27, 2020 (Ethics Committe code: SEMI-COVID-19 27-03-20), as per the guidelines of the Spanish Agency of Medicines and Medical Products. Informed consent was obtained from all participants for using of their medical data for all research derived from the SEMI-COVID-19 registry. Data confidentiality and patient anonymity were maintained at all times, in accordance with Spanish regulations on observational studies.

\section{Consent for publication}

Not applicable.

\section{Competing interests}

The authors hereby declare they have no conflict of interest related to this article.

\section{Author details}

${ }^{1}$ Internal Medicine Department, Gregorio Marañón General University Hospital, Madrid, Spain. ${ }^{2}$ Internal Medicine Department, Puerta de Hierro Majadahonda University Hospital, Madrid, Spain. ${ }^{3}$ Internal Medicine Department, Bellvitge University Hospital-IDIBELL, L'Hospitalet de Llobregat, Barcelona, Spain. ${ }^{4}$ Internal Medicine Department, 12 de Octubre University Hospital, Madrid, Spain. ${ }^{5}$ Internal Medicine Department, La Paz University Hospital, 
Madrid, Spain. ${ }^{6}$ Internal Medicine Department, San Carlos Clinical Hospital, Madrid, Spain. ${ }^{7}$ Internal Medicine Department, Cabueñes University Hospital, Gijón, Asturias, Spain. ${ }^{8}$ Internal Medicine Department, Royo Villanova Hospital, Zaragoza, Spain. ${ }^{9}$ Internal Medicine Department, Santiago Clinical Hospital, Santiago de Compostela, A Coruña, Spain. ${ }^{10}$ Internal Medicine Department, La Princesa University Hospital, Madrid, Spain. ${ }^{11}$ Internal Medicine Department, A Coruña University Hospital, A Coruña, Spain. ${ }^{12}$ Infectious Diseases, Internal Medicine Department, Moisès Broggi Hospital, Sant Joan Despí, Barcelona, Spain. ${ }^{13}$ Internal Medicine Department, Dr. Peset University Hospital, Valencia, Spain. ${ }^{14}$ Internal Medicine Department, Costa del Sol Hospital, Marbella, Málaga, Spain. ${ }^{15}$ Internal Medicine Department, Santa Marina Hospital, Bilbao, Spain. ${ }^{16}$ Internal Medicine Department, Juan Ramón Jiménez University Hospital, Huelva, Spain. ${ }^{17}$ Internal Medicine Department, Henares Hospital, Coslada, Madrid, Spain. ${ }^{18}$ Internal Medicine Department, Badajoz University Hospital Complex, Badajoz, Spain. ${ }^{19}$ Internal Medicine Department, Río Hortega University Hospital, Regional Health Management of Castilla y Leon (SACYL), Valladolid, Spain. ${ }^{20}$ Internal Medicine Department, Infanta Cristina University Hospital, Parla, Madrid, Spain.

\section{Received: 15 February 2021 Accepted: 19 October 2021} Published online: 08 November 2021

\section{References}

1. Wang Z, Yang B, Li Q, et al. Clinical features of 69 cases with coronavirus disease 2019 in Wuhan, China. Clin Infect Dis. 2020;71(15):769-77. https:// doi.org/10.1093/cid/ciaa272.

2. Phelan AL, Katz R, Gostin LO. The novel coronavirus originating in Wuhan, China: challenges for global health governance. JAMA. 2020;323:709-10. https://doi.org/10.1001/jama.2020.1097.

3. World Health Organization. Coronavirus disease (COVID- 19) Situation Report. Accessed 05/31/2021, at https://www.who.int/emergencies/ diseases/novel-coronavirus-2019/situation-reports.

4. Casas-Rojo JM, Antón-Santos JM, Millán-Núñez-Cortés J, et al. Clinical characteristics of patients hospitalized with COVID-19 in Spain: results from the SEMI-COVID-19 Registry. Rev Clin Esp. 2020. https://doi.org/10. 1016/j.rce.2020.07.003.

5. Situación de COVID-19 en España. Ministerio de Sanidad. Centro de Coordinación de Alertas y Emergencias Sanitarias. 2021. Accessed 05/31/2021, at https://cnecovid.isciii.es/covid19/.

6. Pal RK, Naik G, Rathore V, Sahu KK, Kumar R. Comparison between two different successful approaches to COVID-19 pandemic in India (Dharavi versus Kerala). J Family Med Prim Care. 2020;9(12):5827-32. https://doi. org/10.4103/jfmpc.jfmpc_1860_20.

7. Castro MC, Gurzenda S, Macário EM, França GVA. Characteristics, outcomes and risk factors for mortality of 522167 patients hospitalised with COVID-19 in Brazil: a retrospective cohort study. BMJ Open. 2021;11(5): e049089. https://doi.org/10.1136/bmjopen-2021-049089.

8. Weston S, Frieman MB. COVID-19: knowns, unknowns, and questions. mSphere. 2020;5(2):e00203-e220. https://doi.org/10.1128/mSphere. 00203-20.

9. Coronavirus Disease 2019 (COVID-19) Treatment Guidelines. National Institutes of Health, 2020, https://www.covid19treatmentguidelines.nih. gov/.

10. Rawson TM, Moore LSP, Zhu N, et al. Bacterial and fungal co-infection in individuals with coronavirus: a rapid review to support COVID-19 antimicrobial prescribing. Clin Infect Dis. 2020. https://doi.org/10.1093/cid/ciaa5 30.

11. Quinton $L J$, Walkey AJ, Mizgerd JP. Integrative physiology of pneumonia. Physiol Rev. 2018;98(3):1417-64. https://doi.org/10.1152/physrev.00032. 2017.

12. Deng JC. Viral-bacterial interactions-therapeutic implications. Influenza Other Respir Viruses. 2013;7(Suppl3):24-35. https://doi.org/10.1111/irv. 12174.

13. Yamada M, Suzuki H. Influenza virus pneumonia. Ryoikibetsu Shokogun Shirizu, 1999; (24 Pt 2):83-86.

14. Ruuskanen $O$, Lahti $E$, Jennings LC, et al. Viral pneumonia. Lancet. 2011;377(9773):1264-75. https://doi.org/10.1016/S0140-6736(10) 61459-6.
15. Metlay JP, Waterer GW, Long AC, et al. Diagnosis and treatment of adults with community-acquired pneumonia. An Official Clinical Practice Guideline of the American Thoracic Society and Infectious Diseases Society of America. Am J Respir Crit Care Med. 2019;200(7):e45-67. https://doi.org/ 10.1164/rccm.201908-1581ST.

16. Lee MS, Oh JY, Kang Cl, et al. Guideline for antibiotic use in adults with community-acquired pneumonia. Infect Chemother. 2018;50(2):160-98. https://doi.org/10.3947/ic.2018.50.2.160.

17. Feldman C, Anderson R. Antibiotic resistance of pathogens causing community-acquired pneumonia. Semin Respir Crit Care Med. 2012;33(3):232-43. https://doi.org/10.1055/s-0032-1315635.

18. Van Duin D, Paterson DL. Multidrug-resistant bacteria in the community: trends and lessons learned. Infect Dis Clin North Am. 2016;30(2):377-90. https://doi.org/10.1016/j.idc.2016.02.004.

19. Karampela I, Dalamaga M. Could respiratory fluoroquinolones, levofloxacin and moxifloxacin, prove to be beneficial as an adjunct treatment in COVID-19? Arch Med Res. 2020. https://doi.org/10.1016/j.arcmed.2020.06. 004.

20. Novy E, Scala-Bertola J, Roger C, et al. Preliminary therapeutic drug monitoring data of $\beta$-lactams in critically ill patients with SARS-CoV-2 infection. Anaesth Crit Care Pain Med. 2020;39(3):387-8. https://doi.org/10.1016/j. accpm.2020.04.005.

21. Pani A, Lauriola M, Romandini A, et al. Macrolides and viral infections: focus on azithromycin in COVID-19 pathology. Int J Antimicrob Agents. 2020;56(2): 106053. https://doi.org/10.1016/j.jjantimicag.2020.106053.

22. Min JY, Jang YJ. Macrolide therapy in respiratory viral infections. Mediators Inflamm. 2012;2012: 649570. https://doi.org/10.1155/2012/649570.

23. Ohe $M$, Shida $H$, Jodo $S$, et al. Macrolide treatment for COVID-19: will this be the way forward? Biosci Trends. 2020;14(2):159-60. https://doi.org/10. 5582/bst.2020.03058.

24. Bosseboeuf E, Aubry M, Nhan T, et al. Azithromycin Inhibits the replication of Zika virus. J Antivir Antiretrovir. 2018;10(1):6-11. https://doi.org/10. 4172/1948-5964.1000173.

25. Tran DH, Sugamata R, Hirose T, et al. Azithromycin, a 15-membered macrolide antibiotic, inhibits influenza $A(H 1 N 1) p d m 09$ virus infection by interfering with virus internalization process. J Antibiot (Tokyo). 2019;72(10):759-68. https://doi.org/10.1038/s41429-019-0204-x.

26. Huttner BD, Catho G, Pano-Pardo JR, et al. COVID-19: don't neglect antimicrobial stewardship principles. Clin Microbiol Infect. 2020;26(7):808-10. https://doi.org/10.1016/j.cmi.2020.04.024.

27. Baron SA, Devaux C, Colson P, et al. Teicoplanin: An alternative drug for the treatment of coronavirus COVID-19? Int J Antimicrob Agents. 2020;55(4): 105944. https://doi.org/10.1016/j.jjantimicag.2020.105944.

28. Du Y, Tu L, Zhu P, et al. Clinical features of 85 fatal cases of COVID-19 from Wuhan: a retrospective observational study. Am J Respir Crit Care Med. 2020;201(11):1372-9. https://doi.org/10.1164/rccm.202003-0543OC.

29. Zhang J, Zhou L, Yang Y, et al. Therapeutic and triage strategies for 2019 novel coronavirus disease in fever clinics. Lancet Respir Med. 2020;8(3):e11-2. https://doi.org/10.1016/S2213-2600(20)30071-0.

30. Kim D, Quinn J, Pinsky B, et al. Rates of co-infection between SARS-CoV-2 and other respiratory pathogens. JAMA. 2020;323(20):2085-6. https://doi. org/10.1001/jama.2020.6266.

31. Guan WJ, Ni ZY, Hu Y, et al. Clinical characteristics of coronavirus disease 2019 in China. N Engl J Med. 2020;382(18):1708-20. https://doi.org/10. 1056/NEJMoa2002032 (Epub 2020 Feb 28).

32. Zhou F, Yu T, Du R, et al. Clinical course and risk factors for mortality of adult inpatients with COVID-19 in Wuhan, China: a retrospective cohort study. Lancet. 2020;395(10229):1054-62. https://doi.org/10.1016/S01406736(20)30566-3.

33. Wu J, Liu J, Zhao X, et al. Clinical characteristics of imported cases of Coronavirus Disease 2019 (COVID-19) in Jiangsu province: a Multicenter Descriptive Study. Clin Infect Dis. 2020;71(15):706-12. https://doi.org/10. 1093/cid/ciaa199.

34. Argenziano MG, Bruce SL, Slater CL, et al. Characterization and clinical course of 1000 patients with coronavirus disease 2019 in New York: retrospective case series. BMJ. 2020;369: m1996. https://doi.org/10.1136/ bmj.m1996.

35. Suleyman G, Fadel RA, Malette KM, et al. Clinical characteristics and morbidity associated with coronavirus disease 2019 in a series of patients in metropolitan Detroit. JAMA Netw Open. 2020;3(6): e2012270. https:// doi.org/10.1001/jamanetworkopen.2020.12270. 
36. Langford BJ, So M, Raybardhan S, et al. Bacterial co-infection and secondary infection in patients with COVID-19: a living rapid review and metaanalysis. Clin Microbiol Infect. 2020. https://doi.org/10.1016/j.cmi.2020.07. 016.

37. Beović B, Dousak M, Ferreira-Coimbra J, et al. Antibiotic use in patients with COVID-19: a'snapshot'Infectious Diseases International Research Initiative (ID-IRI) survey. J Antimicrob Chemother. 2020. https://doi.org/ 10.1093/jac/dkaa326.

38. Rawson TM, Ming D, Ahmad R, et al. Antimicrobial use, drug-resistant infections and COVID-19. Nat Rev Microbiol. 2020;18(8):409-10. https:// doi.org/10.1038/s41579-020-0395-y.

39. Mirzaei R, Goodarzi P, Asadi M, et al. Bacterial co-infections with SARSCoV-2. IUBMB Life. 2020. https://doi.org/10.1002/iub.2356.10.1002/iub. 2356.

40. Abelenda-Alonso G, Rombauts A, Gudiol C, et al. Influenza and bacterial coinfection in adults with community-acquired pneumonia admitted to conventional wards: risk factors, clinical features, and outcomes. Open Forum Infect Dis. 2020;7(3):ofaa066. https://doi.org/10.1093/ofid/ofaa066.

41. Smith AM, McCullers JA. Secondary bacterial infections in influenza virus infection pathogenesis. Curr Top Microbiol Immunol. 2014;385:327-56. https://doi.org/10.1007/82_2014_394.

42. Jia L, Xie J, Zhao J, et al. Mechanisms of severe mortality-associated bacterial co-infections following influenza virus infection. Front Cell Infect Microbiol. 2017;7:338. https://doi.org/10.3389/fcimb.2017.00338.

43. Katsurada N, Suzuki M, Aoshima M, et al. The impact of virus infections on pneumonia mortality is complex in adults: a prospective multicentre observational study. BMC Infect Dis. 2017;17(1):755. https://doi.org/10. 1186/s12879-017-2858-y.

44. Quah J, Jiang B, Tan PC, et al. Impact of microbial Aetiology on mortality in severe community-acquired pneumonia. BMC Infect Dis. 2018:18(1):451. https://doi.org/10.1186/s12879-018-3366-4

45. Morris DE, Cleary DW, Clarke SC. Secondary bacterial infec-tions associated with influenza pandemics. Front Microbiol. 2017;8:1041. https://doi. org/10.3389/fmicb.2017.01041.

46. Webb SA, Pettilä V, Seppelt I, et al. Critical care services and 2009 H1N1 influenza in Australia and New Zealand. N Engl J Med. 2009;361 (20):192534. https://doi.org/10.1056/NEJMoa0908481.

47. Cillóniz C, Ewig S, Menéndez R, et al. Bacterial co-infection with H1N1 infection in patients admitted with community acquired pneumonia. J Infect. 2012;65(3):223-30. https://doi.org/10.1016/j.jinf.2012.04.009.

48. Rice TW, Rubinson L, Uyeki TM, et al. Critical illness from 2009 pandemic influenza A virus and bacterial coinfection in the United States. Crit Care Med. 2012;40(5):1487-98. https://doi.org/10.1097/CCM.0b013e3182 $416 f 23$.

49. A tool for the potential fall 2009 wave of pandemic $\mathrm{H} 1 \mathrm{~N} 1$ to guide public health decision-making: An overview of the Public Health Agency of Canada's planning considerations, September 2009. Can Commun Dis Rep. 2010; 36(Suppl 3): 1-20. https://doi.org/10.14745/ccdr.v36i00as3.

50. Zahariadis G, Gooley TA, Ryall P, et al. Risk of ruling out severe acute respiratory syndrome by ruling in another diagnosis: variable incidence of atypical bacteria coinfection based on diagnostic assays. Can Respir J. 2006;13(1):17-22. https://doi.org/10.1155/2006/862797.

51. Johansson N, Kalin M, Hedlund J. Clinical impact of combined viral and bacterial infection in patients with community-acquired pneumonia. Scand J Infect Dis. 2011;43(8):609-15. https://doi.org/10.3109/00365548. 2011.570785.

52. Bezerra PGM, Britto MCA, Correia JB, et al. Viral and atypical bacterial detection in acute respiratory infection in children under five years. PLoS ONE. 2011;6(4): e18928. https://doi.org/10.1371/journal.pone.0018928.

53. Crotty MP, Meyers S, Hampton N, et al. Epidemiology, co-infections, and outcomes of viral pneumonia in adults: an observational cohort study. Medicine (Baltimore). 2015;94(50): e2332. https://doi.org/10.1097/MD. 0000000000002332

54. Yang $X, Y u, Y, X u$ J, et al. Clinical course and outcomes of critically ill patients with SARS-CoV-2 pneumonia in Wuhan, China: a singlecentered, retrospective, observational study. Lancet Respir Med. 2020;8(5):475-81. https://doi.org/10.1016/S2213-2600(20)30079-5.

55. Huang $C$, Wang $Y, L i X$, et al. Clinical features of patients infected with 2019 novel coronavirus in Wuhan. China Lancet. 2020;395(10223):497506. https://doi.org/10.1016/S0140-6736(20)30183-5.
56. Chen N, Zhou M, Dong X, et al. Epidemiological and clinical characteristics of 99 cases of 2019 novel coronavirus pneumonia in Wuhan, China: a descriptive study. Lancet. 2020;395(10223):507-13. https://doi.org/10. 1016/S0140-6736(20)30211-7.

57. Bordi L, Nicastri E, Scorzolini L, et al. Differential diagnosis of illness in patients under investigation for the novel coronavirus (SARS-CoV-2), Italy, February 2020. Euro Surveill. 2020;25(8):2000170. https://doi.org/10.2807/ 1560-7917.ES.2020.25.8.2000170.

58. World Health Organization. Clinical management of COVID-19 interim guidance [Internet].Geneva, Switzerland:WorldHealthOrganization; 2020. https:// www.who.int/publications-detail/clinical-management-of-severe-acuterespiratory-infection-when-novel-coronavirus-(ncov)-infection-is-suspected.

59. Alhazzani W, Møller MH, Arabi YM, et al. Surviving Sepsis Campaign: guidelines on the management of critically ill adults with Coronavirus Disease 2019 (COVID-19). Intensive Care Med. 2020;46(5):854-87. https:// doi.org/10.1007/s00134-020-06022-5.

60. Shi H, Han X, Jiang N, et al. Radiological findings from 81 patients with COVID-19 pneumonia in Wuhan, China: a descriptive study. Lancet Infect Dis. 2020;20(4):425-34. https://doi.org/10.1016/S1473-3099(20)30086-4.

61. Klein EY, Monteforte B, Gupta A, et al. The frequency of influenza and bacterial coinfection: a systematic review and meta-analysis. Influenza Other Respir Viruses. 2016;10(5):394-403. https://doi.org/10.1111/irv.12398.

62. Richter S, Parolin C, Palumbo M, et al. Antiviral properties of quinolonebased drugs. Curr Drug Targets Infect Disord. 2004;4(2):111-6. https://doi. org/10.2174/1568005043340920.

63. Marciniec K, Beberok A, Boryczka S, et al. Ciprofloxacin and moxifloxacin could interact with SARS-CoV-2 protease: preliminary in silico analysis (3/23/2020). https://doi.org/10.2139/ssrn.3562475.

64. Garcia-Vidal C, Sanjuan G, Moreno-Garcia E, et al. Incidence of Coinfections and superinfections in hospitalized patients with COVID-19: a retrospective cohort study. Clin Microbiol Infect. 2020. https://doi.org/10. 1016/j.cmi.2020.07.041.

65. Zhu N, Zhang D, Wang W, et al. A novel coronavirus from patients with pneumonia in China, 2019. N Engl J Med. 2020;382(8):727-33. https://doi. org/10.1056/NEJMoa2001017.

66. Liang WH, Guan WJ, Li CC, et al. Clinical characteristics and outcomes of hospitalised patients with COVID-19 treated in Hubei (epicentre) and outside Hubei (non-epicentre): a nationwide analysis of China. Eur Respir J. 2020;55(6):2000562. https://doi.org/10.1183/13993003.00562-2020.

67. Randomised Evaluation of COVID-19 Therapy (RECOVERY Trial). Principal investigator: Peter W Horby. University of Oxford. ClinicalTrials.gov number NCT04381936; ISR number 50189673.

68. Touret F, Gilles M, Barral K, et al. In vitro screening of a FDA approved chemical library reveals potential inhibitors of SARS-CoV-2 replication. Sci Rep. 2020;10(1):13093. https://doi.org/10.1038/s41598-020-70143-6.

69. Gautret P, Lagier JC, Parola P, et al. Hydroxychloroquine and azithromycin as a treatment of COVID-19: results of an open-label non-randomized clinical trial. Int J Antimicrob Agents. 2020;56(1): 105949. https://doi.org/ 10.1016/j.ijantimicag.2020.105949.

70. Bengoechea JA, Bamford CG. SARS-CoV-2, bacterial co-infections, and AMR: the deadly trio in COVID-19? EMBO Mol Med. 2020;12(7): e12560. https://doi.org/10.15252/emmm.202012560.

71. Hendaus MA, Jomha FA. Covid-19 induced superimposed bacterial infection. J Biomol Struct Dyn. 2020. https://doi.org/10.1080/07391 102.2020.1772110.

72. Rawson TM, Moore LSP, Castro-Sanchez E, et al. COVID-19 and the potential long-term impact on antimicrobial resistance. J Antimicrob Chemother. 2020;75(7):1681-4. https://doi.org/10.1093/jac/dkaa194.

73. Sharland M, Pulcini C, Harbarth S, et al. Classifying antibiotics in the WHO essential medicines list for optimal use-be AWaRe. Lancet Infect Dis. 2018;18(1):18-20. https://doi.org/10.1016/S1473-3099(17)30724-7.

74. Mayi BS, Mainville M, Altaf R, Lanspa M, Vaniawala S, Ollerhead TA, Raja A. A crucial role for antimicrobial stewardship in the midst of COVID-19. J Microbiol Biol Educ. 2021. https://doi.org/10.1128/jmbe.v22i1.2285.

75. Sehgal K, Fadel HJ, Tande AJ, Pardi DS, Khanna S. Outcomes in patients with SARS-CoV-2 and Clostridioides difficile coinfection. Infect Drug Resist. 2021;28(14):1645-8. https://doi.org/10.2147/IDR.S305349.

\section{Publisher's Note}

Springer Nature remains neutral with regard to jurisdictional claims in published maps and institutional affiliations. 